\title{
Idaho National Laboratory Cultural Resource Monitoring Report for FY 2009
}

October 2009

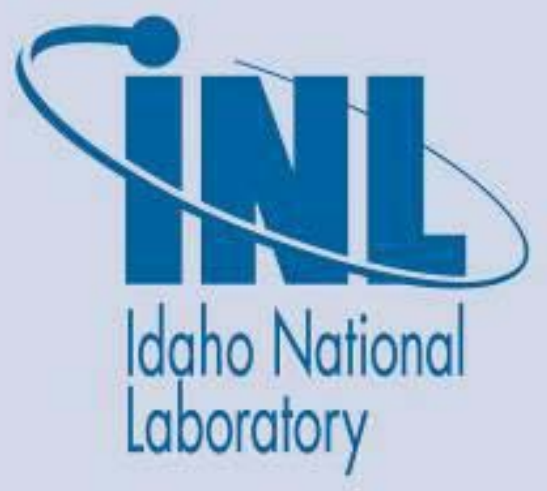

The INL is a U.S. Department of Energy National Laboratory operated by Battelle Energy Alliance 


\section{DISCLAIMER}

This information was prepared as an account of work sponsored by an agency of the U.S. Government. Neither the U.S. Government nor any agency thereof, nor any of their employees, makes any warranty, expressed or implied, or assumes any legal liability or responsibility for the accuracy, completeness, or usefulness, of any information, apparatus, product, or process disclosed, or represents that its use would not infringe privately owned rights. References herein to any specific commercial product, process, or service by trade name, trade mark, manufacturer, or otherwise, does not necessarily constitute or imply its endorsement, recommendation, or favoring by the U.S. Government or any agency thereof. The views and opinions of authors expressed herein do not necessarily state or reflect those of the U.S. Government or any agency thereof. 


\title{
Idaho National Laboratory Cultural Resource Monitoring Report for FY 2009
}

\author{
INL Cultural Resource Management Office
}

October 2009

Idaho National Laboratory Environmental Stewardship and Water Management Idaho Falls, Idaho 83415

Prepared for the U.S. Department of Energy Office of Nuclear Energy Under DOE Idaho Operations Office

Contract DE-AC07-05ID14517 



\begin{abstract}
This report describes the cultural resource monitoring activities of the Idaho National Laboratory's (INL) Cultural Resource Management (CRM) Office during fiscal year 2009 (FY 2009). Throughout the year, thirty-eight cultural resource localities were revisited including: two locations with Native American human remains, one of which is a cave, two additional caves, twenty-two prehistoric archaeological sites, six historic homesteads, two historic stage stations, two historic trails, and two nuclear resources, including Experimental Breeder Reactor-I, which is a designated National Historic Landmark. Several INL project areas were also monitored in FY 2009 to assess project compliance with cultural resource recommendations and monitor the effects of ongoing project activities. Although impacts were documented at a few locations and trespassing citations were issued in one instance, no significant adverse effects that would threaten the National Register eligibility of any resources were observed. Monitoring also demonstrated that several INL projects generally remain in compliance with recommendations to protect cultural resources.
\end{abstract}




\section{CONTENTS}

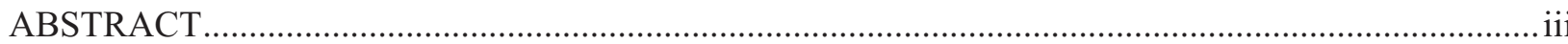

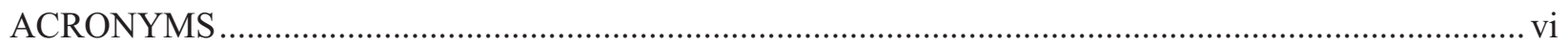

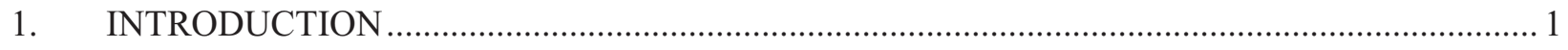

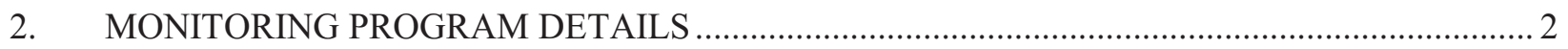

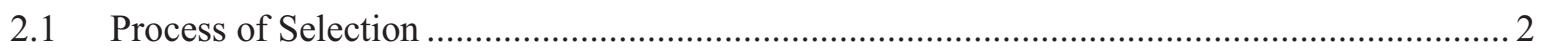

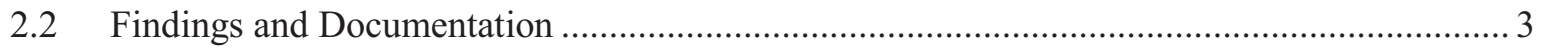

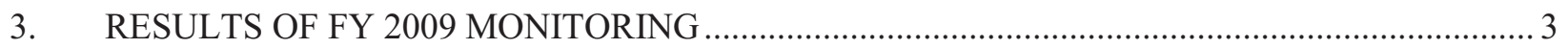

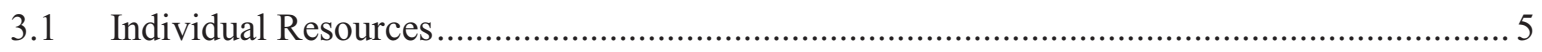

3.1.1 Native American Human Remains ....................................................................... 5

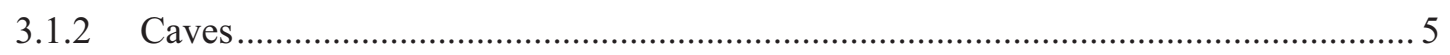

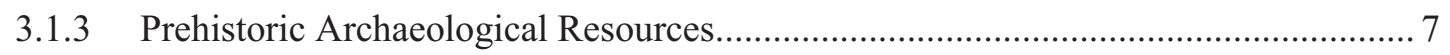

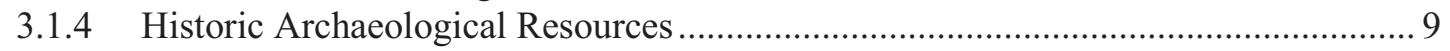

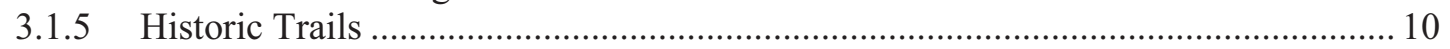

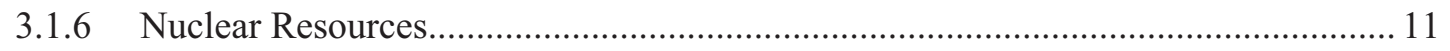

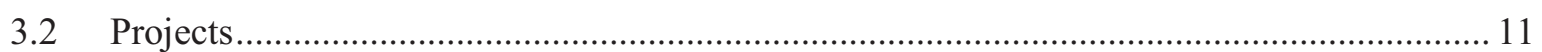

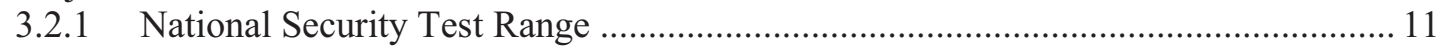

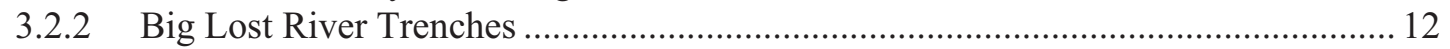

3.2.3 Geophysical Surveys for Subsurface Unexploded Ordnance .................................. 12

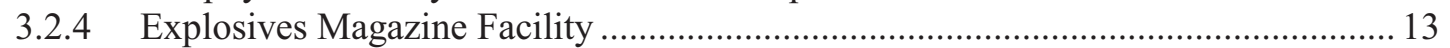

3.2.5 Power Burst Facility-Critical Infrastructure Test Range Complex ........................... 13

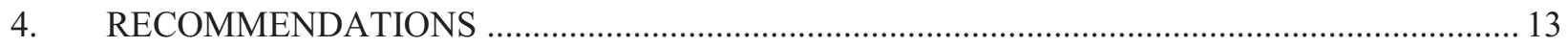

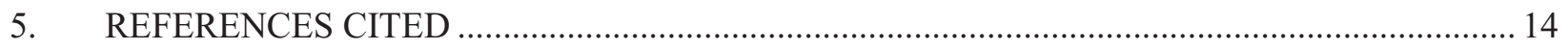

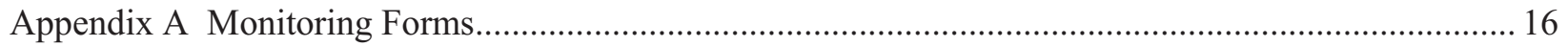

\section{FIGURES}

Figure 1. DOE-ID, INL CRM and HeTO tribal representatives at Middle Butte Cave in FY 2009.......... 4

Figure 2. Trash removed from Middle Butte Cave in FY 2009............................................................ 7

Figure 3. Fresh tire tracks documented at the Pioneer Site in FY 2009 .............................................. 8

Figure 4. Impacts resulting from range fire and wind erosion at site 10-BT-1062 in FY 2009................ 9 


\section{ACRONYMS}

\begin{tabular}{|c|c|}
\hline ARPA & Archaeological Resources Protection Act \\
\hline ATV & all terrain vehicle \\
\hline BEA & Battelle Energy Alliance \\
\hline $\mathrm{BM}$ & Bingham (county) \\
\hline BT & Butte (county) \\
\hline BLM & Bureau of Land Management \\
\hline CITRC & Critical Infrastructure Test Range Complex \\
\hline CRM & cultural resource management \\
\hline CWI & CH2M Hill-Washington Group Idaho, LLC \\
\hline DOE-ID & Department of Energy, Idaho Operations Office \\
\hline EBR-I & Experimental Breeder Reactor-I \\
\hline FY & fiscal year \\
\hline GPS & global positioning system \\
\hline НеTO & Heritage Tribal Office \\
\hline ICP & Idaho Cleanup Project \\
\hline HTRE & Heat Transfer Reactor Experiment \\
\hline INL & Idaho National Laboratory \\
\hline $\mathrm{JF}$ & Jefferson (county) \\
\hline LWP & Laboratory Wide Procedure \\
\hline MCP & Management Control Procedure \\
\hline NEPA & National Environmental Policy Act \\
\hline NRHP & National Register of Historic Places \\
\hline PBF & Power Burst Facility \\
\hline SHPO & State Historic Preservation Office \\
\hline U.S. & United States \\
\hline UXO & unexploded ordnance \\
\hline WERF & Waste Experimental Reduction Facility \\
\hline
\end{tabular}




\section{Idaho National Laboratory Cultural Resource Monitoring Report for FY 2009}

\section{INTRODUCTION}

The Idaho National Laboratory (INL) is an 890 square mile federal reserve covering portions of five counties on the northeastern edge of the Snake River Plain in southeastern Idaho (Irving 1993, DOE-ID 1996). Lands included within the boundaries of the INL are under the jurisdiction of the U.S. Department of Energy, Idaho Operations Office (DOE-ID) and have been set aside since the 1940s to support many kinds of scientific and engineering research. Currently, four main contractors perform work for DOE-ID at INL. Battelle Energy Alliance (BEA) is the primary Management and Operations contractor, where the INL Cultural Resource Management (CRM) Office is based. CH2MHill/Washington Group (CWI) takes the lead on many cleanup operations related to the Idaho Cleanup Project (ICP), and Bechtel-Babcock \& Wilcox-XT, Idaho leads many activities for the Advanced Mixed Waste Treatment project located within the Radioactive Waste Management Complex. INL's Naval Reactor Facility is under the jurisdiction of the U.S. DOE's Naval Reactors Office and is currently managed and operated by Bechtel-Bettis.

Public access to INL has been restricted since its inception in the 1940s and an active security force patrols all lands and facilities. When encountered, trespassers are removed immediately and can be served with official citations. Largely as a result of long term access restrictions, many cultural resources on the INL are relatively undisturbed. Vandalism is also reduced due to ongoing security patrols. However, over the past decade, unauthorized access has been noted at some INL cultural resource sites, particularly those within hunting and grazing easements, or with easy access from the paved roads that bisect or are adjacent to INL boundaries. This may be related to reductions in INL Security programs (i.e. elimination of daily helicopter patrols).

Access restrictions and security patrols do not prevent all impacts and damage to cultural resources does occur. There are five primary sources of impact:

- Natural processes such as erosion from wind and water or animal burrowing

- Livestock grazing, herding, and associated operations (i.e. watering stations/troughs, feed transport, stock camps)

- Trespassing in highly sensitive areas and unauthorized artifact collection by members of the public and possibly INL employees unaware of or indifferent to penalties associated with these activities

- INL projects that fail to comply with recommendations to protect cultural resources as outlined in Environmental Checklists or other environmental guidance

- Lack of regular maintenance or inappropriate preservation treatments for historic architectural properties

Under DOE-ID's INL Cultural Resource Management Plan (DOE-ID 2009), BEA's INL CRM Office maintains an ongoing program for monitoring, assessing, and developing strategies to mitigate impacts to cultural resources as a result of these sources of impact. This report provides a summary of the cultural resource monitoring activities completed in fiscal year (FY) 2009. 


\section{MONITORING PROGRAM DETAILS}

A detailed description of the INL CRM Office monitoring program is located in Appendix L of the INL Cultural Resource Management Plan (DOE-ID 2009). Monitoring enables INL CRM staff to determine if the integrity of known resources is being compromised by natural processes, by unauthorized activities, by lack of maintenance or inappropriate preservation measures, or by INL projects. When impacts to cultural resources are identified in this manner, actions to avert further deterioration can be initiated and federal stewardship responsibilities are fulfilled.

\subsection{Process of Selection}

Specific cultural resources are chosen for monitoring based on INL CRM Office priorities as well as feedback from DOE-ID, the Shoshone-Bannock Tribes Heritage Tribal Office (HeTO), and INL stakeholders. The INL CRM archives, which include documentation of over 2,500 archaeological resources and more than 200 historic architectural properties, are also consulted for appropriate candidates for yearly monitoring. Both DOE-ID and the Shoshone-Bannock Tribes are often directly involved in fieldwork during the monitoring activities and INL project managers and other stakeholders, such as the Idaho State Historic Preservation Office (SHPO), also participate occasionally. Certain resources, like Middle Butte, Prickly, and Aviators Caves, sensitive localities inside the Power Burst Facility (PBF, now Critical Infrastructure Test Range Complex-CITRC), and the Experimental Breeder Reactor-I (EBR-I) National Historic Landmark, are monitored every year. Others, such as historic homesteads and some prehistoric archaeological sites are also visited routinely because of their location in highly visible areas where trespassing has been documented in the past. Each year INL CRM staff also conducts surveillance of resources in a wide variety of settings to address ongoing research interests and the overall focus of INL construction and project activities.

Monitoring of INL projects is completed under direct project funding and may be included as part of an INL Environmental Checklist or other environmental guidance. In FY 2009 monitoring was targeted at several different INL activities and involved different INL contractors. In one FY 2009 example, monitoring was stipulated as part of "Findings of No Significant Impact" associated with a National Environmental Policy Act (NEPA) Environmental Assessment for BEA's National Security Test Range (DOE-ID 2007a). In another example, CWI's ongoing geophysical surveys to identify unexploded ordnance (UXO) were evaluated for cultural resource impacts in an INL CRM Office effort that has spanned three years. Project-specific monitoring is also routinely completed in the sandy aeolian soils inside the boundaries of the PBF-CITRC area, where Native American human remains have been discovered in both primary and secondary (i.e. disturbed) contexts. Cultural resource monitoring of projects that involve soil disturbance within this facility complex is routine and required by company procedures (e.g. BEA's LWP-8000 and CWI's MCP-3480). This level of cultural resource oversight ensures that any new discoveries of human remains will be managed appropriately.

Forms developed by INL CRM Office staff are completed for every cultural resource monitoring trip. Hard-copy and electronic versions of these documents are maintained in the INL CRM files and are reproduced for FY 2009 here in Appendix A to this report. INL CRM staff also archive a variety of photographs to document monitoring efforts, but these high quality electronic images are reproduced here only in part due to their large size. 


\subsection{Findings and Documentation}

Under the INL CRM monitoring program, there are four possible findings for a given monitoring trip, based on the level of disturbance noted:

- Type 1: no visible changes to a cultural resource and/or a project is operating within the limits of cultural resource clearance recommendations

- Type 2: impacts are noted but do not threaten the National Register eligibility of a cultural resource and/or a project is operating outside of culturally cleared limitations but no cultural resources have been adversely impacted

- Type 3: impacts are noted that threaten the National Register eligibility of a cultural resource and/or a project has been operating outside of culturally cleared limitations and impacts to non-eligible cultural resources have occurred

- Type 4: impacts that threaten the National Register eligibility of a cultural resource are occurring during the monitoring visit, justifying the use of the INL Stop Work Authority (LWP-14002, MCP553)

If Type 2, 3, or 4 impacts are documented during a monitoring trip, notifications are made to project managers, the DOE-ID cultural resources coordinator, and various other parties, as appropriate and according to the nature and severity of the disturbance. Typically, Type 2 impacts can be corrected at once with the cooperation of INL project managers, security personnel, and/or landlord organizations. In these instances, the impacts are only reported in summary fashion in year end reports. Some Type 2 and all Type 3 or 4 impacts prompt formal investigations by the INL CRM Office. INL project managers, security, and/or landlord organizations, DOE-ID, and Shoshone-Bannock tribal representatives may also participate in these investigations.

Results of all monitoring and formal impact investigations are summarized annually in a year-end report to DOE-ID (cf. INL CRM 2009) and also appear in a higher level summary of INL CRM Office yearly activities (cf. Braun et al. 2007) that is sent to DOE-ID and other parties such as the Idaho State Historic Preservation Office, the Shoshone-Bannock Tribes, and other stakeholders.

\section{RESULTS OF FY 2009 MONITORING}

In FY 2009, 60 monitoring forms (Appendix A) were completed throughout the year to document individual site visits, to assess project compliance with cultural resource recommendations, to confirm the locations of specific cultural resources in relation to project activities, and to watch for cultural materials during ground disturbing activities in sensitive areas. Representatives from INL projects, DOE-ID, and the Shoshone-Bannock Tribe's HeTO participated in several of the trips in FY 2009 (Figure 1).

Throughout the year, some Type 2 impacts, including unauthorized visitation and off-road vehicle use, animal burrowing, erosion, and inadequate building maintenance were documented and trespassers apprehended by INL security forces at a sensitive cave location were cited. However, the National Register integrity of all of the resources that were monitored remains intact. No adverse impacts were documented. 


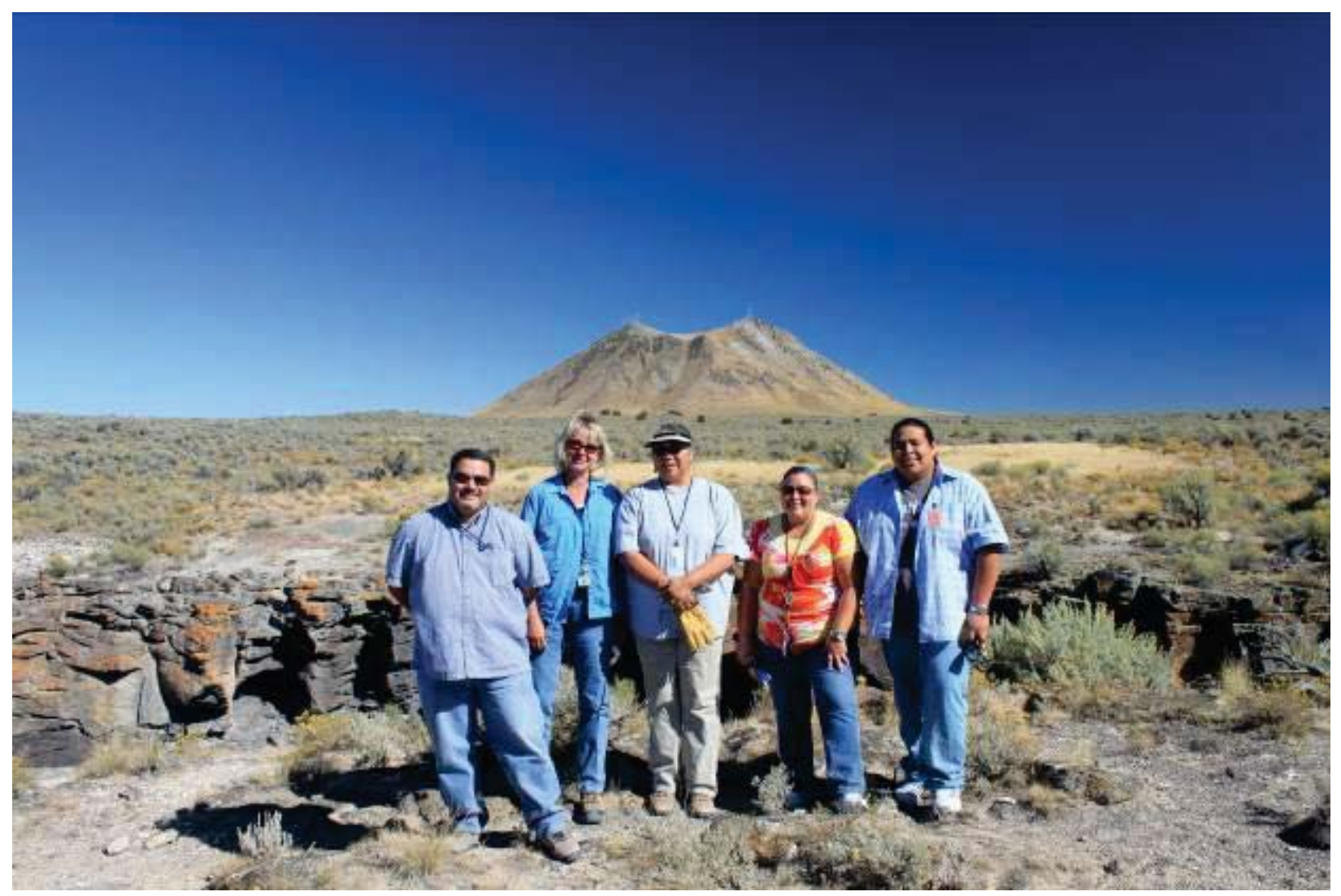

Figure 1. DOE-ID, INL CRM and HeTO tribal representatives at Middle Butte Cave in FY 2009.

In an effort to address recurring Type 2 impacts in FY 2009, INL CRM staff took steps to initiate a new productive working relationship with U.S. federal agents experienced in enforcing the Archaeological Resource Protection Act (ARPA) and successfully prosecuting individuals who have violated the law. To initiate a dialog in FY 2009, two Special Agents with the Department of the Interior U. S. Fish and Wildlife Service Division of Law Enforcement and a DOE-ID Security Specialist were escorted to several key archaeological sites on the INL that are particularly sensitive and that also receive occasional or regular unauthorized visitation from site employees and/or the public. Discussions between the agents and INL CRM staff resulted in the following ideas to pursue for mitigation:

- Internal notifications from DOE as a reminder to employees in regard to ARPA and other preservation laws

- INL procedural disciplinary actions

- Installation of remote surveillance equipment to document unauthorized visitors and activities

It is anticipated that interaction and cooperation between the federal agents, DOE-ID security, and the INL CRM Office will be ongoing through FY 2010 and beyond, leading to more effective protections for sensitive INL cultural resources. 


\subsection{Individual Resources}

In FY 2009, INL CRM staff conducted official surveillance of thirty-eight individual cultural resources including: two locations with Native American human remains, one of which is a cave, two additional caves, twenty-two prehistoric archaeological sites, six historic homesteads, two historic stage stations, two historic trails, the Heat Transfer Reactor Experiment (HTRE) airplane engines and associated locomotive, and the Experimental Breeder Reactor-I National Historic Landmark. As noted in the discussions to follow, a handful of resources were visited on multiple occasions. Forms that document individual observations and recommendations are included in Appendix A.

\subsubsection{Native American Human Remains}

Two INL localities that include sensitive Native American human remains are visited at least once a year for monitoring and stabilization, as necessary. These are the Waste Experimental Reduction Facility (WERF) remains (10-BT-2046), located within the PBF-CITRC area, and Prickly Cave (10-BT-2037).

The WERF location (10-BT-2046) consists of sensitive human remains that were found eroding from the floor surface of an artificial drainage basin in FY 1996. Investigations confirmed that these sensitive materials were resting in their original position and in consultation with the Shoshone-Bannock Tribes steps were taken to secure them and prevent any future disturbance. Today these remains are secure beneath four truck loads of clean soil. The area is monitored yearly with the assistance of HeTO tribal representatives. Fortunately, no new impacts have ever been discovered.

Prickly Cave (10-BT-2037) is a relatively small lava tube cave with a correspondingly small opening that is flush with the exterior ground surface. Cultural materials located on the cave exterior are characterized by a light and unremarkable scatter of lithic debris along with a few stone tools. The cave interior however, houses extremely sensitive human remains along with various perishable (wood, bone) tools. The remains consist of skeletal elements originally found in the cave as well as some that were repatriated to Prickly Cave from another INL location. Over the years that annual monitoring has been conducted at Prickly Cave no evidence of human disturbance has been found. However, during a FY 2008 monitoring trip a human mandible previously noted inside the cave was found approximately 10 meters from the cave opening. It was concluded that the mandible had most likely been moved by a coyote. The mandible was returned to the cave and secured next to the repatriated human remains. Fortunately, the 2009 monitoring visit found no signs of disturbance, either to the human remains in the cave or to artifacts surrounding the cave entrance.

In FY 2009, no new or adverse impacts were observed at either of these locations and measures to stabilize the sensitive remains appear to remain adequate. Natural forces such as erosion and burrowing animals remain the primary agents of the light, Type 2 impacts that are occasionally observed in these areas and both warrant continued surveillance and intervention, as necessary.

\subsubsection{Caves}

As of FY 2009, 27 caves have been inventoried within the boundaries of the INL. Geologically, biologically, and culturally, each of these resources is unique. Humans have been drawn to these locations for thousands of years seeking shelter, work areas, and unique opportunities for caching food and valuables. Some caves have also served unique roles in hunting, spirituality, religion, communication, and education. Sensitive archaeological materials (e.g. human remains, perishable artifacts, fragile deposits underfoot) and cultural features (e.g. pictographs, rock features, hearths) remain today as a fragile record of these many uses. These materials exhibit remarkable potential for providing information of value in understanding the past and as a result, many caves are eligible for nomination to the National Register of Historic Places. 
Caves retain enduring cultural significance to the Shoshone-Bannock Tribes and HeTO tribal representatives are important partners in INL CRM Office efforts to protect these sensitive resources from impact. DOE-ID supports these efforts and is committed to assuring continued tribal access to these important places.

Public and scientific interests in lava tube caves are also high. Access to INL caves is limited to official tours, but each year a large number of INL employees, school children, and educators gain an appreciation for local Native American people and their desert home during occasional tours. New scientific investigations are also routinely conducted at INL caves, with past research focused on the geology of the caves, resident and fossil plant and animal populations, and sensitive archaeological deposits.

Due to their high sensitivity, a variety of INL caves are monitored every year and some locations are visited several times per year. In spite of official access restrictions, unauthorized visitation continues to be a problem at some locations. The INL CRM Office continues to seek ways of reducing these impacts and in FY 2009, enlisted the assistance of federal agents from the U. S. Department of the Interior with specific training and interest in violations of the Archaeological Resources Protection Act (ARPA). In FY 2010 additional options for protection will be explored with these federal agents and DOE-ID Security.

Monitoring was conducted at three sensitive caves in FY 2009: Prickly Cave, Middle Butte Cave, and Aviators Cave. Monitoring results for Prickly Cave are presented in Section 3.1.1 and discussions for the other two monitored resources are below. Additional detail can also be found in Appendix A.

\subsubsection{Middle Butte Cave}

Middle Butte Cave (10-BM-34) is a large lava tube, with a cavernous opening and a subterranean extent of nearly 0.4 mile. Artifacts and paintings on the walls, both ancient and modern, indicate that the Cave has been a destination for human populations for a very long time. The Cave is of particular significance to the Shoshone-Bannock Tribes and DOE-ID has recognized their interests in a Memorandum of Agreement that assures continued access for ceremonial, cultural, and educational activities (DOE-ID 1994).

Restrictions on access to Middle Butte Cave have been in place for decades but unauthorized visitation continues to be a problem despite efforts by INL Security and the INL CRM Office. Vandals have fired bullets into signs at the area and continue to drive around existing barriers. In FY 2008, teenaged vandals were reprimanded by INL Security for unauthorized visitation and escorted to the Cave to remove graffiti that they had left in the furthest reaches of the lava tube interior. In FY 2009, increased vigilance by INL Security resulted in the apprehension of three trespassers who used four-wheelers to access the Cave illegally. After additional investigation, these individuals were charged with trespass violations, including jail time (suspended) for one culprit.

Multiple monitoring visits were made to Middle Butte Cave throughout FY 2009, both before and after the trespassing violations. Concrete evidence of unauthorized visitation was documented (Figure 2) and the offending trash was removed. Discussions with federal agents and DOE-ID Security will continue into FY 2010 to devise more effective ways of deterring this activity. 


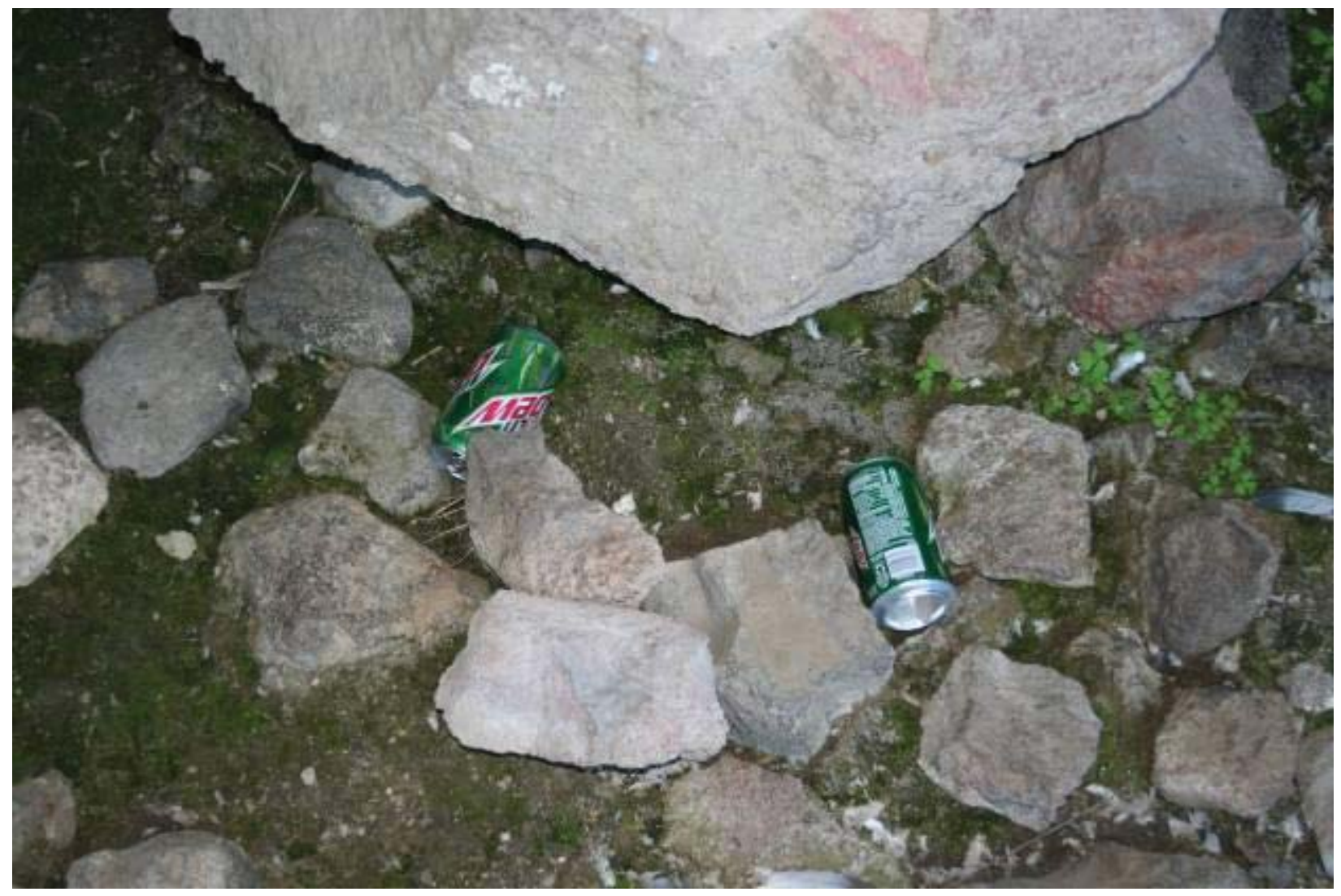

Figure 2. Trash removed from Middle Butte Cave in FY 2009.

\subsubsection{Aviators Cave}

Aviators Cave (10-BT-1582) is another large INL lava tube with extensive evidence of prehistoric use and contemporary significance to the Shoshone-Bannock Tribes. It is monitored for impacts at least once a year. Tribal participation in annual monitoring has become increasingly important since 2002, because at this time tribal representatives returned an especially sensitive item to an area in the Cave that is known only to them. On yearly visits, they inform INL CRM staff of any changes. Fortunately, there have been no disturbances to this item noted to date. However, since FY 2000, when a large range fire burned through the area, unauthorized visitation has been on the increase. Incursions were initially via 4-wheel drive vehicle in FY 2000, but since vegetation has returned, trespassers appear to be arriving on foot and new footprints are noted nearly every year. In FY 2008, a small pile of artifacts left in a "discard" pile near the Cave entrance appeared to represent an escalation in unauthorized activities.

Fortunately in FY 2009 there was no evidence of new impacts or unauthorized visitors at Aviators Cave. The high sensitivity of this location makes it an ideal choice for future INL CRM Office efforts in cooperation with federal agents and DOE-ID Security and additional protections for the site will be sought through this relationship in FY 2010.

\subsubsection{Prehistoric Archaeological Resources}

There are thousands of prehistoric archaeological sites within INL boundaries, ranging in age from more than 12,000 to 150 years old. The great antiquity and excellent condition of many of these sites is notable and provides justification for routine visitation and care to prevent adverse impacts. In FY 2009, 
INL CRM staff monitored four large and highly visible prehistoric archaeological sites during routine visits with the following results:

- No new impacts were documented in the assemblage of Pleistocene-aged lithic artifacts at the WindGap Folsom Site (10-BT-1449)

- No new impacts were observed in the dispersed scatter of lithic artifacts and possible fire hearths exposed at a large campsite adjacent to the Big Lost River Sinks (10-BT-738)

- Fresh vehicle tracks (Type 2 impacts) were documented through the Pioneer Site (10-BT-676) in an area that has been previously disturbed by vehicles (Figure 3)

- No new impacts from the nearby National Security Test Range or any other INL activities were observed at the rock walls and dense artifact scatter at the campsite known as "Hellofasite"

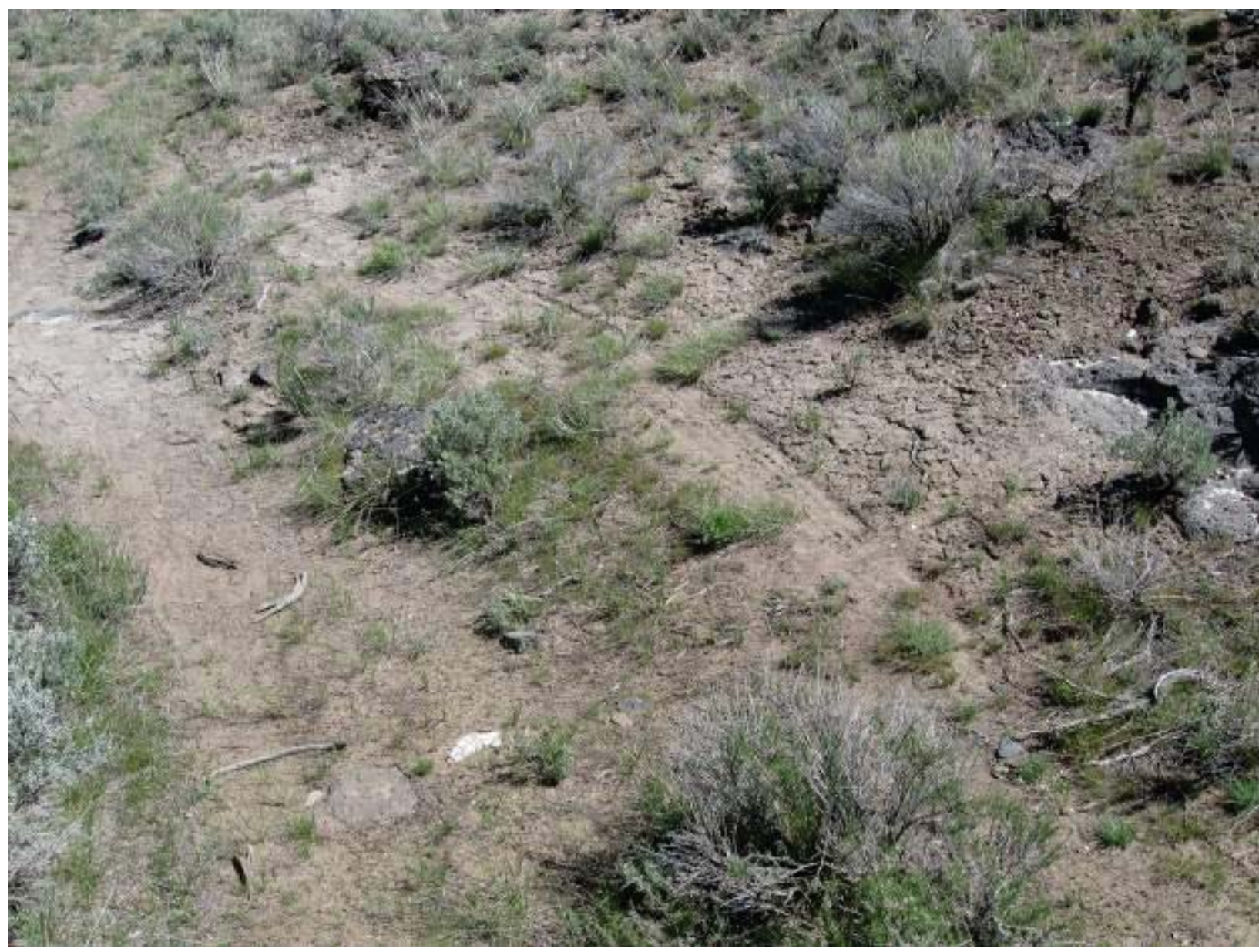

Figure 3. Fresh tire tracks documented at the Pioneer Site in FY 2009.

A proposed upgrade to the existing T-25 power line road stretching between the Materials and Fuels Complex (MFC) and CITRC prompted INL CRM Office monitoring visits to confirm the locations of known prehistoric archaeological sites in relation to the proposed road work. Monitoring forms were completed to document the condition of the fourteen sites that were revisited since many had not been evaluated recently. Sites included were: 10-BM-109, 10-BM-110, 10-BM-112, 10-BM-115, 10-BM-116, 10-BM-117, 10-BM-118, 10-BT-1049, 10-BT-1052, 10-BT-1053, 10-BT-1059, 10-BT-1062, 10-BT- 
1247, 10-BT-1063. No adverse impacts were observed, although range fires, wind erosion, and firefighting efforts had recently caused light impacts in some areas (Figure 4). Once the locations were confirmed, recommendations to avoid any new impacts during future road upgrade activities were provided (Pace 2008). Later in FY 2009, plans for this road upgrade were cancelled.

Prehistoric archaeological sites were also monitored in FY 2009 to assess impacts in relation to ongoing INL project activities. Section 3.2 provides additional detail on all project-specific monitoring. In one project area, where UXO evaluations are ongoing, monitoring forms were completed to document the condition of four archaeological sites that had not been re-visited since their original recording in 1996 (10-BT-2050, 10-BT-2051, 10-BT-2052, 10-BT-2053). In all cases, these artifact assemblages present at these locations were similar to those originally observed although new artifacts were noted in some cases, probably as a result of greater ground visibility due to a past range fire. Additional detail on the light impacts resulting from geophysical surveys is provided in Section 3.2.3 and equipment cart through the site boundaries caused negligible impacts, comparable in intensity to heavy foot traffic.

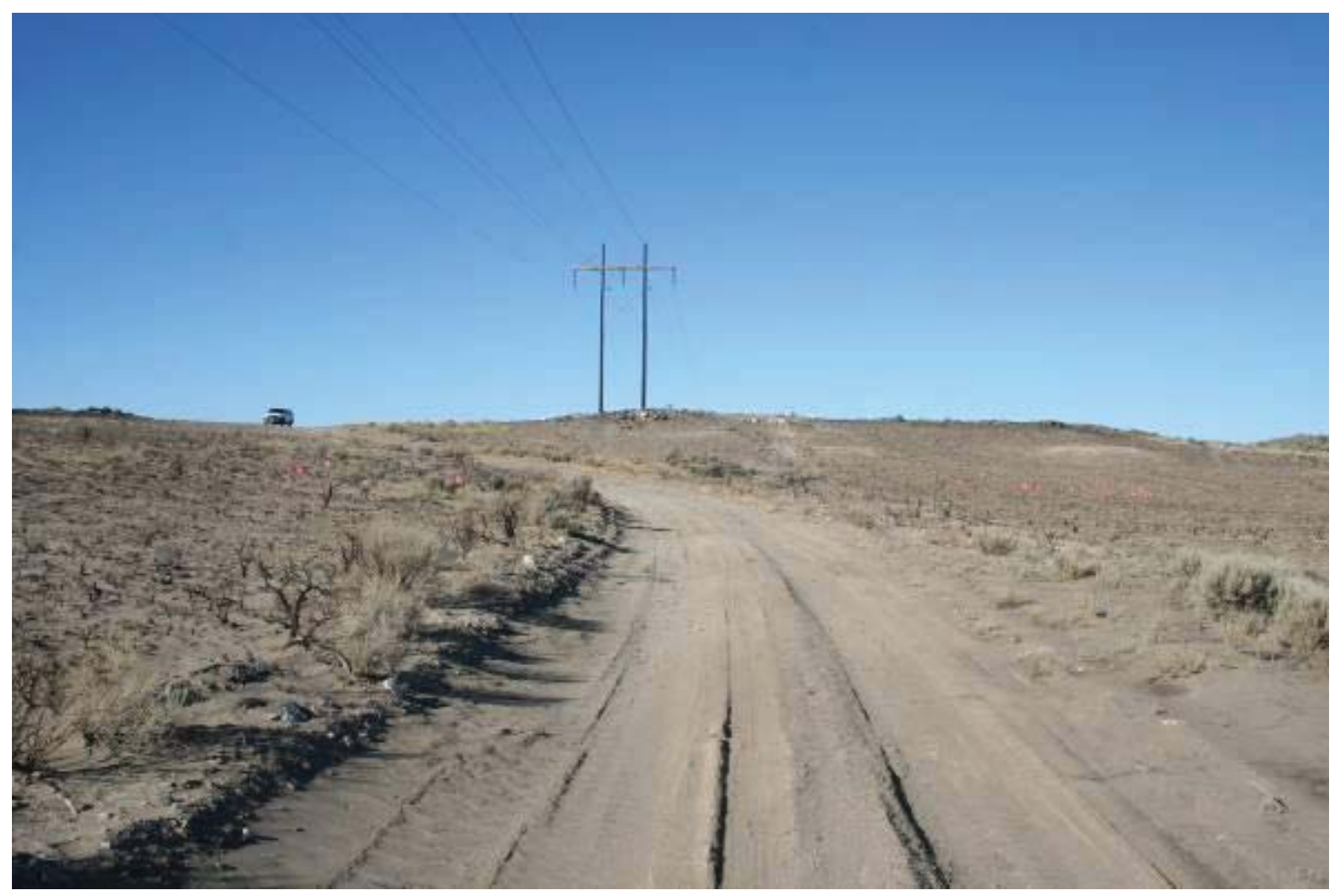

Figure 4. Impacts resulting from range fire and wind erosion at site 10-BT-1062 in FY 2009.

\subsubsection{Historic Archaeological Resources}

During the period from 1884 to roughly 1930, many settlers filed homestead claims on lands that would eventually be designated as the INL. Federal laws that encouraged settlement of western deserts were often catalysts for these activities and in the INL region the Desert Land Act of 1877, Carey Land Act of 1894 and the Desert Reclamation Act of 1902 were influential. Many types of historic archaeological sites remain from this time, including homesteads, stage and freighting stations, town sites and railroad sidings, ditches and canals, and the construction camps that were often necessary to build and 
support them. INL CRM Office monitoring of several of these historic archaeological resources is routine. In FY 2009, two historic stage stations and six homesteads were visited.

\subsubsection{Stage Stations}

At the Birch Creek Stage Station (BEA-07-32-115) in a remote area near the northernmost boundary of the INL, fresh tire tracks indicated some unauthorized visitation but grazing-related impacts appeared to have decreased in FY 2009. The relative isolation of this sensitive location makes it vulnerable to additional unauthorized activities and regular monitoring will continue in an effort to prevent impacts from becoming adverse.

The Powell Stage Station (10-BT-2194) was visited on multiple occasions during the year due to high levels of project-related activities in the vicinity. Revegetation of backhoe trenches has changed native ungulate grazing patterns in the area, but impacts to the archaeological site are not adverse. Likewise, geophysical surveys employing a 6-wheeler and equipment cart in regular transects over the surface of the site created impacts comparable to heavy foot traffic and no adverse effects. However, potentially adverse Type 2 impacts were noted as a result of animal burrowing in the southwestern corner of the rock foundation and northeast portion of bridge abutments on the site. INL CRM staff will continue to monitor this damage and consider consulting with experts in animal control/behavior to develop strategies to discourage additional damage of this nature.

\subsubsection{Historic Homesteads}

In FY 2009, six historic homesteads were visited by INL CRM staff including three localities associated with historic trail T-16 (Lilly Wakefield Homestead-BEA-07-32-107, BEA-07-32-106, BEA07-32-105), the Richards Homestead (BEA-06-31-Richards), the Kuharski homestead (BEA-07-32-114), and a site near the Idaho Nuclear Technology Center (INTEC) (10-BT-269). Although no significant adverse impacts were noted at any of these localities, some Type 2 impacts worthy of continued monitoring were documented.

At the Lilly Wakefield site, large badger dens were noted around and under the cistern and foundation. At the Kuharski homestead, rodent burrows near the blacksmith forge appear to remain inactive but recent trash indicates that unauthorized visitors have accessed the area. Light vehicle tracks passing along a protective fence line at 10-BT-269 indicated some recent visitation and prompted a follow-up reminder to INL project personnel that unrestricted off-road vehicle use is prohibited. Though no adverse impacts have occurred, ongoing observation is warranted and these sites will be included in future monitoring efforts.

\subsubsection{Historic Trails}

INL lands are crossed by a multitude of unimproved trails, many dating to historic times around the turn of the $20^{\text {th }}$ Century. These trails were important links between communities along the Snake River (e.g. Blackfoot and Eagle Rock/Idaho Falls) and those located in mountain valleys to the west and north (e.g. Mackay, Howe, Arco). People, goods, and stock passed freely along the established paths and encouraged economic growth in the region. Continued sporadic travel on the trails today by modern vehicles ensures that they remain visible on the contemporary landscape. However, heavy vehicle and stock traffic and inappropriate maintenance can adversely impact the trails, destroy their context and setting, and adversely impact archaeological resources nearby.

In FY 2009, adverse impacts related to inappropriate FY 2002 maintenance were still visible along one important INL trail, Goodale's Cutoff. Fortunately, undisturbed segments of this northern spur of the Oregon Trail do remain on INL lands and in places, exhibit original wear from wagon wheels as well as metal scrapings, loose horse shoe nails, and broken wagon parts, over rocky outcrops where the going 
was rough. No new impacts to Goodale's Cutoff were observed in FY 2009 and the road appeared to be subject to only light ongoing use.

A similar situation is present along portions of the length of T-16, also monitored in FY 2009. This trail passes by many historic homesteads on the way south to the Cerro Grande townsite/railroad siding. Although monitoring showed that the trail is not heavily used now, impacts from aggressive FY 2007 maintenance (addition of gravel to low-lying areas) were still apparent. Monitoring and consultation will continue at these and other INL trails to encourage appropriate use and maintenance and prevent further deterioration.

\subsubsection{Nuclear Resources}

Experimental Breeder Reactor-I (EBR-I) is INL's single designated National Historic Landmark, recognized as such because of its association with the early development of nuclear power and reactor technology. It is the only INL facility open to the public on a seasonal basis (Memorial Day through Labor Day, annually). In past years, the site has benefited from a "Save America's Treasures" grant, which supported updated exhibits to enhance the Visitors Center and addressed some preservation issues (brick and mortar restoration) (Braun 2006). Nuclear artifacts exhibited at the site include two Heat Transfer Reactor Experiment (HTRE) airplane engines and the specialized locomotive used to position them during experiments in the 1950s. These resources are eligible for nomination to the National Register. A nomination package for the HTRE engines has been submitted to DOE-ID and will be modified to include the locomotive.

In FY 2009, monitoring was completed for the HTRE nuclear artifacts as well as the EBR-I reactor facility. At the HTRE engines, which are located outdoors and exposed to the elements, weather (sun, rain, freeze, thaw) and nesting birds continue to cause impacts. If these conditions are not corrected, adverse impacts are likely to result. Consultation will be ongoing with DOE-ID and facility managers toward a solution in FY 2010. At the EBR-I reactor facility, no new impacts were observed in FY 2009 but an inadequate water drainage system continues to threaten the integrity of bricks and mortar on the building. INL CRM staff will continue to work with DOE-ID and INL landlord organizations to address ongoing maintenance and preservation at these important, highly visible, public resources.

\subsection{Projects}

Several types of project-specific cultural resource monitoring were conducted in FY 2009. Nearly twenty archaeological sites previously recorded in the vicinity of new INL projects were revisited to assess their current condition and develop recommendations for avoiding future impact. Discussions of these reviews were presented in Section 3.1 according to the types of resources investigated. In a second type of project monitoring in FY 2009, INL projects were audited for compliance with cultural resource recommendations made during the INL environmental review process. Finally, in a third type of project monitoring, ground disturbance associated with INL project activities in archaeologically sensitive areas was directly observed by INL CRM staff. In total, five projects were monitored. Results appear in the Sections to follow.

\subsubsection{National Security Test Range}

The Environmental Assessment (EA) completed for the National Security Test Range (DOE-ID 2007) included minimal requirements for protection of cultural resources such as:

- Limit ATV travel and signage [around the safety fan perimeter] to areas outside the boundaries of any identified cultural resources to prevent disturbance 
- Support yearly visits of known archaeological resources in the project area by an INL archaeologist and take additional protective measures as necessary

- Coordinate work with an INL archaeologist to avoid blading and leveling activities inside the boundaries of identified archaeological sites

Several project activities at the National Security Test Range were monitored in FY 2009 in response to this guidance. The Range safety fan was examined to ensure that the vehicle used to install signs correctly followed the route marked by INL CRM staff to avoid impacts to archaeological sites identified there in FY 2008. Project compliance was confirmed and no impacts were observed. INL CRM staff will continue to cooperate with project personnel on yearly monitoring of the fan to reduce or eliminate the need for off-road vehicle use around the fan. In another effort, no new impacts or evidence of unauthorized visitation were observed during a routine visit to the sensitive prehistoric campsite with rock features known as "Hellofasite" (10-JF-88) located to the east of the Test Range.

Ground disturbance and revegetation activities conducted along the T-25 access road approximately 50 meters away from a known archaeological site (10-BM-124) were directly observed as they occurred and no sensitive artifacts were uncovered at any time. Surveillance was also conducted at eight prehistoric lithic scatters located along the T-25 access road (10-JF-85, 10-JF-84, 10-JF-83, 10-JF-80, 10 JF-78, 10-JF-77, 10-BM-123, BEA-06-20-07). INL CRM staff worked closely with project personnel to clearly mark the sensitive areas and reinforce the need to avoid blading and leveling activities within them in compliance with the EA. Efforts to convince project personnel to support a better long term solution for protecting the sensitive resources along the T-25 access road are ongoing.

\subsubsection{Big Lost River Trenches}

In 2002, DOE-ID, the U. S. Bureau of Reclamation, and various University partners initiated a paleohydrology study to develop a defensible and consistent interpretation of flood history and flood hazards on the INL. Several backhoe trenches excavated into Big Lost River floodplain deposits near the modern riverbed were necessary to support this investigation. In FY 2007, the trenches were backfilled and in FY 2008 they were revegetated with native seeds and seedlings. INL CRM staff and ShoshoneBannock tribal representatives were on hand to monitor all ground disturbances due to the proximity of four sensitive archaeological sites (prehistoric archaeological sites - 10-BT-2189, 10-BT-2192, 10-BT2193 and the Powell Stage Station - 10-BT-2194) and the requirements of a National Environmental Policy Act Environmental Assessment (DOE-ID 2002). No sensitive cultural materials were observed at any time during trenching, backfilling, or revegetation. During monitoring in FY 2009, archaeological materials appeared to be stabilized. Light impacts as a result of grazing and wind erosion were documented, but no significant adverse impacts were observed.

\subsubsection{Geophysical Surveys for Subsurface Unexploded Ordnance}

Cleanup of unexploded ordnance (UXO), ordnance components, and explosive compounds that remain from the period when INL was operated as the Arco Naval Proving Ground (ca. 1942 - 1949, 1968) has been ongoing at INL since 1994. In FY 2009, geophysical surveys continued to evaluate UXO that still remains beneath the surface at identified ordnance areas, utilizing cart-mounted magnetometers and a 6-wheeled all terrain vehicle to collect data.

In the gravelly floodplain soils that have been mapped with the ATV-cart setup to date, impacts have been minimal. In sandier deposits, slight lateral displacement of soils has been observed in the tracks of the ATV, but even these effects in these particular soils have proven to be negligible and not much greater than heavy foot traffic. In FY 2009, mapping efforts were focused at the Exploded Railcar Area.

Operations were again monitored by INL CRM staff to determine if known archaeological resources were being adversely impacted by the work. As was documented in FY 2007 and again in FY 2008, no 
adverse impacts occurred when ATV transects passed over the surface at four previously recorded prehistoric campsites (10-BT-2050, 10-BT-2051, 10-BT-2052, 10-BT-2053) and several additional newly recorded historic and prehistoric archaeological sites. Ground surfaces displayed no adverse impacts and no artifacts were broken or displaced. The ATV and cart will be considered and evaluated for use in other ordnance cleanup areas on a case-by-case basis and INL CRM monitoring will continue into FY 2010 as strategies for cleanup of the identified UXO are developed.

Data collected during the geophysical surveys are also being evaluated for use in future archaeological investigations. In this context, the 6-wheeler and cart were utilized to collect geophysical data from the Powell Stage Station in FY 2009. Monitoring at this location after data collection also showed no adverse impacts to the sensitive historic archaeological materials. Analysis is ongoing and INL CRM staff believes this may prove to be a valuable tool in future archaeological evaluations.

\subsubsection{Explosives Magazine Facility}

The National Security Test Range and MFC Security proposed in FY 2008 to construct a new facility to safely store explosives. The preferred area for construction was in a disturbed area east of the Test Range T-25 access road. Archaeological survey in FY 2008 revealed surface artifacts in sandy soils on the eastern edge of this project area and a potential for additional buried cultural deposits in the surrounding sandy soils. Test excavations in FY 2009 to the west of the surface artifacts revealed no sensitive cultural deposits in the project area. The archaeological site located near this project area was visited on two occasions in FY 2009, first to familiarize HeTO tribal counterparts with the resource before test excavations and later to confirm project compliance with recommendations for avoidance of direct impact where artifacts occur. No new impacts were observed at the site at any time.

\subsubsection{Power Burst Facility-Critical Infrastructure Test Range Complex}

Company environmental procedures require project managers to contact the INL CRM Office in advance of ground disturbance within the fenced boundary of PBF-CITRC. This is due to the occurrence of human remains in original as well as secondary (i.e. disturbed) contexts at two separate locations within the facility. Accelerated cleanup across the INL and new activities to support National Security have resulted in an increase in the number of projects at this facility. In FY 2009, these activities included training exercises, power line testing, cell tower installation, electrical trenching, and demolition. On eight occasions in FY 2009, ground disturbance of this nature was monitored for human remains. No sensitive materials were observed at any time.

\section{RECOMMENDATIONS}

Monitoring is an effective method of documenting impacts to INL cultural resources and is a necessary first step in prevention. Several broad recommendations result from FY 2009 surveillance. First, at a minimum, the condition of the following resources of high sensitivity should be assessed in FY 2010:

- WERF Remains (10-BT-2046)

- Prickly Cave (10-BT-2037)

- Middle Butte Cave (10-BM-34)

- Aviators Cave (10-BT-1582)

- $\quad$ Pioneer Site (10-BT-676) 
- Powell Stage Station (10-BT-2194)

- Goodale's Cutoff

- Experimental Breeder Reactor I National Historic Landmark

Cultural resource monitoring in FY 2010 should also be focused on several broad classes of other INL cultural resources and projects, as funding allows. Minimally, this might include:

- Any soil disturbance at the PBF-CITRC area to monitor for additional occurrences of sensitive human remains, even in disturbed contexts

- Areas burned by wildfire

- Archaeological sites located in high traffic areas such as the INL Boundary and Grazing Boundary or where unauthorized visitation is likely

- Historic homesteads, including those identified during ongoing archival research

- $\quad$ Buttes, craters, and caves

- World War II buildings and features at Central Facilities Area and within the broader Naval Proving Ground

- INL gun and test range safety fans

- UXO geophysical surveys and proposed cleanup activities

- Grazing and grazing-related impacts to historic trails

To address ongoing Type 2 impacts related to unauthorized visitation, INL CRM staff will continue to work closely with DOE-ID, HeTO tribal representatives, INL security and landlord organizations, and individual project personnel, as appropriate, to implement more effective protections. In FY 2010, assistance offered by federal experts in Archaeological Resource Protection Act (ARPA) enforcement should enhance this team and the tools and plans developed for resource protection.

\section{REFERENCES CITED}

Braun, J. B., 2006, “Experimental Breeder Reactor I Historic Structure Report, INL/EXT-06-1 1909. Idaho Falls, ID.

Braun, J. B., H. Gilbert, D. Lowrey, C. Marler, and B. R. Pace, 2007, "INL Cultural Resource Management Annual Report FY 2007," INL-EXT-08-14071. Idaho Falls, ID.

DOE-ID, 1994, Memorandum of Agreement, "Middle Butte Cave," between the U. S. Department of Energy, Idaho Operations Office and the Shoshone-Bannock Tribes, January 26, 1994.

DOE-ID, 1996, “Comprehensive Facility and Land Use Plan,” DOE/ID-10514. Idaho Falls, ID.

DOE-ID, 2002, Final Environmental Assessment for Geomorphic Investigations of the Big Lost River at Site BLR-8 on the INEEL, DOE/EA-1448, September 2002.

DOE-ID, 2007, "Final Environmental Assessment for the National Security Test Range," DOE/EA-1557, April 2007. Idaho Falls, ID.

DOE-ID, 2009, "Idaho National Laboratory Cultural Resource Management Plan," DOE/ID-10997, Rev 3. Idaho Falls, ID. 
INL CRM, 2009, "Idaho National Laboratory Cultural Resource Monitoring Report for FY 2008," INL/EXT-09-15319. Idaho Falls, ID.

Irving, J. S., editor, 1993, "Environmental Resource Document for the Idaho National Engineering Laboratory," EGG-WMO-10279. Idaho Falls, ID.

LWP-8000, BEA (INL) Laboratory-Wide Procedure, Environmental Instructions for Facilities, Processes, Materials and Equipment.

LWP-14002, BEA (INL) Laboratory-Wide Procedure, Stop Work Actions.

MCP-553, CWI (ICP) Step Back and Stop Work Authority.

MCP-3480, CWI (ICP) Management Control Procedure, Environmental Instructions for Facilities, Processes, Materials and Equipment.

Pace, B. R., 2008, “Archaeological Investigation of the East Loop Power Line Road (T-25) on the INL," INL/EXT-08-15039. Idaho Falls, ID. 


\section{Appendix A}

\section{Monitoring Forms}




\section{Appendix A Monitoring Forms}

Appendix A contains electronic versions of FY 2009 monitoring forms originally completed in the field. In a few cases, multiple field visits to the same site location are documented on a single form. FY 2009 forms are organized according to the following categories presented in the preceding report:

- Native American Human Remains

- Caves

- Prehistoric Archaeological Resources

- Historic Archaeological Resources

- Historic Trails

- Nuclear Resources

- Projects 
A: Native American Human Remains 
Monitor Number: CFM-09-09

Monitor Name: $\quad$ C.F. Marler, Julie Braun, Robert Gallegos, Carolyn Smith, Tino Batt, Sherice Gould

Monitor Date(s): $\quad$ 9/23/09

Project: $\quad$ NA

Site Name/Number: $\quad$ Prickly Cave

Reason for Monitoring: routine

Findings: $\quad$\begin{tabular}{|l|l|l|l|}
\hline Type 1 & $\mathrm{x}$
\end{tabular}$\quad$\begin{tabular}{|l|l|}
\hline Type 2 & Type 3 \\
\hline
\end{tabular}

Impact Agent(s): $\quad$ No new impacts

Significance of Impact:

Did disturbance or impact extend into undisturbed areas?

If yes, describe:

NA Yes

No

Work Halted? NA Yes $\square$ No $\square$

If yes, describe:

Notifications:

Date Contacted:

Contact Method:

Cultural Materials Observed?

If yes, describe: Thin scatter of lithic debitage and a few diagnostic tools surrounding the cave exterior; Human remains in the cave interior were undisturbed. A packrat was observed inside the cave.

Cultural Materials Collected?

Yes $\square$ No $x$

If yes, describe: No collection.

General Comments:

Recommendations: Continue to monitor at least twice annually

GPS Coordinates collected?

If yes, describe (datum, coordinates):

Yes $\square$ No $\mathrm{X}$

Attach additional documentation, as warranted (photos, profiles, etc.) $\quad$ Yes $\square$ No $\quad$ No If yes, describe: 
Monitor Number: $\quad$ CFM-09-10

Monitor Name: $\quad$ C.F. Marler, Julie Braun, Robert Gallegos, Carolyn Smith, Tino Batt, Sherice Gould Monitor Date(s): $\quad$ 9/23/09

Project: $\quad$ NA

Site Name/Number: $\quad$ WERF burial

Reason for Monitoring: routine

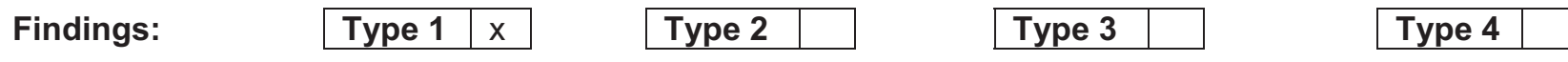

Impact Agent(s): $\quad$ Erosion, rodent burrowing- neither of which appears recent

Significance of Impact: Not significant

Did disturbance or impact extend into undisturbed areas?

If yes, describe:

NA Yes

No

Work Halted? NA Yes $\square$ No $\square$

If yes, describe:

Notifications:

Date Contacted:

Contact Method: | E-mail $\quad$ Phone $\square$ Official correspondence, CCN\#:

Cultural Materials Observed? Yes $\square$ No $\mathrm{X}$

If yes, describe:

Cultural Materials Collected? NA Yes $\square \quad$ No

If yes, describe:

General Comments: Moderate erosion along the south and west periphery of the soil cap although vegetation has stabilized most of the cap. Minor small rodent burrowing in evidence.

Recommendations: Continue to monitor once per year

GPS Coordinates collected?

If yes, describe (datum, coordinates):

Yes $\square$ No $\mathrm{X}$

Attach additional documentation, as warranted (photos, profiles, etc.) $\quad$ Yes $\square$ No $\quad$ X If yes, describe: 


\section{A: Caves}


Idaho National Laboratory Cultural Resource Management Office Field Monitoring Form

Monitor Number:

Monitor Name:

CFM-09-03

C.F. Marler, Julie Braun, Dino Lowrey, John and Amy Dudgeon, Robert Gallegos, Carolyn Smith, Tino Batt, Sherice Gould

Monitor Date(s): $\quad$ 5/18/09, 6/28/09, 9/23/09

Project:

Site Name/Number: $\quad$ 10BM34 (Middle Butte Cave)

Reason for Monitoring: Routine

\begin{tabular}{l|l|l|l|l|} 
Findings: & Type 1 & $\mathrm{x}$
\end{tabular}$\quad$\begin{tabular}{|l|l|}
\hline Type 2 & Type 3 \\
\hline
\end{tabular}

Impact Agent(s): No new impacts

Significance of Impact:

Did disturbance or impact extend into undisturbed areas?

If yes, describe:

NA Yes $\square$ No

Work Halted? NA Yes $\square$ No

If yes, describe:

Notifications: N/A

Date Contacted:

Contact Method:

N/A

Cultural Materials Observed? Yes $x$
If yes, describe: Thin scatter of lithic debitage

Official correspondence, CCN\#:

If yes, describe: Thin scatter of lithic debitage and historic trash surrounding the cave exterior; pictographs inside the cave

Cultural Materials Collected?

Yes $\square$ No $x$

If yes, describe: No collection.

General Comments:

Recommendations: Continue to monitor at least twice annually

GPS Coordinates collected?

If yes, describe (datum, coordinates):

Yes $\square$ No $\mathrm{X}$

Attach additional documentation, as warranted (photos, profiles, etc.) $\quad$ Yes $\square$ No $\quad$ X If yes, describe: 
Monitor Number: CFM-09-07

Monitor Name: $\quad$ C.F. Marler

Monitor Date(s): $\quad 7 / 14 / 09$

Project: $\quad$ NA

Site Name/Number: $\quad$ 10BM34 (Middle Butte Cave)

Reason for Monitoring: Follow-up to reports of trespassers apprehended by INL security

\begin{tabular}{l|l|l|l|l|}
\hline Findings: & Type 1 & $\mathrm{x}$ & Type 2 & Type 3 \\
\hline
\end{tabular}

Impact Agent(s): $\quad$ No new impacts

Significance of Impact:

Did disturbance or impact extend into undisturbed areas?

If yes, describe:

NA Yes $\square$ No

Work Halted? NA Yes $\square$ No $\square$

If yes, describe:

Notifications: $\quad$ Robert Gallegos, Chris Heyer

Date Contacted:

Contact Method: | E-mail $\quad \mathrm{X}$ Phone $\quad \square$ Official correspondence, CCN\#:

$\begin{array}{llll}\text { Cultural Materials Observed? No } & \text { Yes } \mathrm{x}\end{array}$

If yes, describe: Thin scatter of lithic debitage and historic trash surrounding the cave exterior; pictographs inside the cave.

Cultural Materials Collected? Yes $\square$ No $\mathrm{x}$

If yes, describe: No collection.

General Comments: No evidence of damage or vandalism was found either outside the cave or in the cave near the front. (A complete search of the cave was not conducted). Most importantly there was no damage to the pictographs.

Recommendations: $\quad$ Continue to monitor at least twice annually

GPS Coordinates collected?

If yes, describe (datum, coordinates):

Attach additional documentation, as warranted (photos, profiles, etc.) If yes, describe:

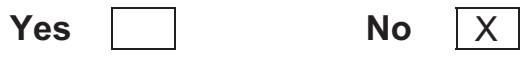

Yes $\square$ No $\mathrm{X}$ 
Monitor Number:

Monitor Name:

Monitor Date(s):

CFM-09-12

C.F. Marler, Dino Lowrey

Project:

$8 / 17 / 09$

Site Name/Number:

NA

Reason for Monitoring:

10BM34 (Middle Butte Cave)

Tribal tour

Findings:

\begin{tabular}{|l|l|}
\hline Type 1 & \\
\hline
\end{tabular}

\begin{tabular}{|l|l|}
\hline Type 2 & $\mathrm{X}$ \\
\hline
\end{tabular}

\begin{tabular}{|l|l|}
\hline Type 3 & \\
\hline
\end{tabular}

Type 4

Impact Agent(s): $\quad$ New Mountain Dew cans noted in the cave interior

Significance of Impact: Not significant- does not affect National Register Eligibility

Did disturbance or impact extend into undisturbed areas?

If yes, describe:

NA Yes

No

Work Halted?

If yes, describe:

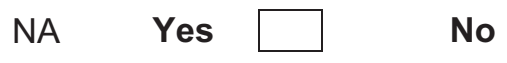

Notifications:

Date Contacted:

Contact Method:

| E-mail $\square$ Phone $\square$ Official correspondence, CCN\#:

Cultural Materials Observed? Yes $x$

No $\square$

If yes, describe: Thin scatter of lithic debitage and historic trash surrounding the cave exterior; pictographs inside the cave.

Cultural Materials Collected?

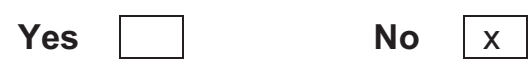

If yes, describe: No collection.

General Comments: Cans may have been left by the trespassers arrested in July. Cans were not collected during the Tribal tour but were retrieved 2 days later by Julie Braun and Hollie Gilbert.

Recommendations: The frequency of anomalous events at Middle Butte Cave suggests the need to increase annual visits to a minimum of three formal monitoring trips. In addition to formal visits, additional periodic checks should be done as time and schedules allow.

GPS Coordinates collected?

If yes, describe (datum, coordinates):

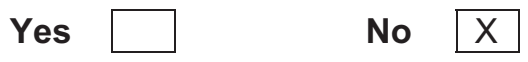

Attach additional documentation, as warranted (photos, profiles, etc.) Yes No $\mathrm{X}$ If yes, describe: 
Monitor Number:

Monitor Name:

Monitor Date(s):

HKG-09-05

Hollie K. Gilbert and Julie B. Braun

$8 / 19 / 09$

Project:

Tour with Special Agents from the U.S. Fish and Wildlife Service

Site Name/Number: $\quad$ Middle Butte Cave

Reason for Monitoring: Tour of key archaeological sites at the INL

\section{\begin{tabular}{l|l|l|l|l|} 
Findings: & Type 1 & $\mathrm{x}$ & Type 2 &
\end{tabular}$\quad$\begin{tabular}{|l|l|}
\hline Type 3 \\
Type 4
\end{tabular}}

Impact Agent(s): $\quad$ Two Mt. Dew cans were noted in the entrance to the cave.

Significance of Impact: Unauthorized visitation.

Did disturbance or impact extend into undisturbed areas? $\quad$ Yes $\quad$\begin{tabular}{l|l|l|} 
No \\
\hline
\end{tabular}

If yes, describe:

Work Halted?

If yes, describe:

Notifications:

Date Contacted:

Contact Method:

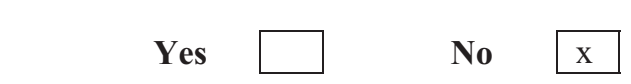

Cultural Materials Observed? Yes $\square$ No $\mathrm{x}$

If yes, describe: Cultural materials appear to be undisturbed.

Cultural Materials Collected? Yes $\square$ No $\mathrm{x}$

If yes, describe: No collection.

General Comments: Cans were photographed and then removed from cave.

Recommendations: Whenever new trash is found, it needs to be collected for disposal. In addition to the Mt. Dew cans, other older trash was collected such as a piece of wire, broken glass, and $.22 \mathrm{cal}$. bullet casings.

GPS Coordinates collected?

Yes $\square$ No $\mathrm{x}$

If yes, describe (datum, coordinates):

Attach additional documentation, as warranted (photos, profiles, etc.) $\quad$ Yes $\quad x \quad$ No $\square$ If yes, describe: 
Idaho National Laboratory Cultural Resource Management Office Field Monitoring Form

Monitor Number: CFM-09-06

Monitor Name: $\quad$ C.F. Marler, Julie Braun, Dino Lowrey, John \& Amy Dudgeon

Monitor Date(s): $\quad 6 / 28 / 09$

Project: $\quad$ NA

Site Name/Number: Aviator's Cave

Reason for Monitoring: routine

\begin{tabular}{l|l|l|l|l|}
\hline Findings: & Type 1 & $\mathrm{x}$ & Type 2 &
\end{tabular}$\quad$\begin{tabular}{|l|l|}
\hline Type 3 \\
\hline
\end{tabular}

Impact Agent(s): No new impacts

Significance of Impact:

Did disturbance or impact extend into undisturbed areas?

If yes, describe:

NA Yes $\square$ No

Work Halted? NA Yes $\square$ No $\square$

If yes, describe:

Notifications:

Date Contacted:

Contact Method: | E-mail $\square$ Phone $\square$ Official correspondence, CCN\#:

$\begin{array}{llll}\text { Cultural Materials Observed? } & \text { Yes } \mathrm{x} \text { No }\end{array}$

If yes, describe: Dense lithic scatter surrounding the lava tube collapse

Cultural Materials Collected? Yes $\square$ No $\mathrm{x}$

If yes, describe: No collection.

General Comments:

Recommendations: monitor twice per year

GPS Coordinates collected?

If yes, describe (datum, coordinates):

Yes $\square$ No $\mathrm{X}$

Attach additional documentation, as warranted (photos, profiles, etc.) $\quad$ Yes $\quad \square \quad$ No $\quad$ X If yes, describe: 
A: Prehistoric Archaeological Sites 
Idaho National Laboratory Cultural Resource Management Office Field Monitoring Form

Monitor Number: CFM-09-01

Monitor Name: $\quad$ C.F. Marler, Julie Braun

Monitor Date(s): $\quad 5 / 18 / 09$

Project:

NA

Site Name/Number: $\quad$ 10BT1449

Reason for Monitoring: Routine
Findings:
\begin{tabular}{|l|l|}
\hline Type 1 & $\mathrm{x}$ \\
\hline
\end{tabular}
Type 2
Type 3
Impact Agent(s): $\quad$ Site has been extensively impacted in the past- likely related to historic

Type 4

RWMC operations. No new impacts noted

Significance of Impact: $\quad$ NA

Did disturbance or impact extend into undisturbed areas?

If yes, describe:

NA Yes $\square$ No

Work Halted?

If yes, describe:

Notifications:

Date Contacted:

Contact Method:

NA Yes $\square$ No

No $\square$

Cultural Materials Observed?

If yes, describe:

$$
\text { N/A }
$$

E-mail

Phone

Official correspondence, CCN\#:

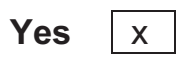

No

variably dense lithic scatter- site has been recorded/sampled on 2 occasions with diagnostic tools and some debitage collected. No additional diagnostics noted on this visit.

Cultural Materials Collected?

Yes $\square$ No $x$

If yes, describe: No collection.

General Comments:

Recommendations: Continue to monitor annually

GPS Coordinates collected?

Yes $\square$ No $\mathrm{X}$

If yes, describe (datum, coordinates):

Attach additional documentation, as warranted (photos, profiles, etc.)

Yes

No $\mathrm{X}$

If yes, describe: 
Monitor Number: CFM-09-02

Monitor Name: $\quad$ C.F. Marler, Julie Braun

Monitor Date(s): $\quad 5 / 18 / 09$

Project: $\quad$ NA

Site Name/Number: $\quad$ 10BT676 (Pioneer)

Reason for Monitoring: $\quad$ Routine

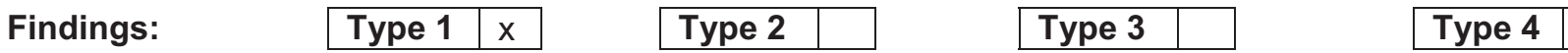

Impact Agent(s): $\quad$ Site has been extensively impacted in the past by railroad construction, vehicular traffic, natural erosion, bioturbation, probable looting etc. Possible fresh vehicle tracks noted.

Significance of Impact: Not significant- tracks were located in previously disturbed portions of the Site- Does not affect National Register eligibility

Did disturbance or impact extend into undisturbed areas?

If yes, describe:

Work Halted?

If yes, describe:

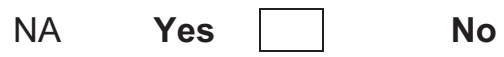

Notifications: N/A

Date Contacted:

Contact Method: E-mail Phone $\square$ Official correspondence, CCN\#:

$\begin{array}{llll}\text { Cultural Materials Observed? } & \text { Yes } & x & \end{array}$

If yes, describe: Extensive lithic scatter along with fire-cracked rock, a few potsherds and a major historic component.

Cultural Materials Collected?

Yes $\square$ No $x$

If yes, describe: No collection.

General Comments:

Recommendations: Continue to monitor annually

GPS Coordinates collected?

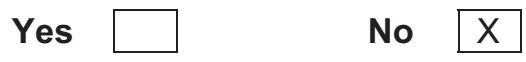

If yes, describe (datum, coordinates):

Attach additional documentation, as warranted (photos, profiles, etc.)

If yes, describe: Photo of possibly fresh tire tracks

Yes $X$ No 
Idaho National Laboratory Cultural Resource Management Office Field Monitoring Form

Monitor Number: CFM-09-11

Monitor Name: $\quad$ C.F. Marler, Julie Braun, Robert Gallegos, Carolyn Smith, Tino Batt, Sherice Gould

Monitor Date(s): $\quad$ 9/23/09

Project: $\quad$ NA

Site Name/Number: $\quad$ Big Lost River Sinks (General Area)- also 10BT738

Reason for Monitoring: routine

\begin{tabular}{l|l|l|l|l|}
\hline Findings: & Type 1 & $\mathrm{x}$ & Type 2 &
\end{tabular}$\quad$\begin{tabular}{|l|l|}
\hline Type 3 \\
\hline
\end{tabular}

Impact Agent(s):

Significance of Impact:

Did disturbance or impact extend into undisturbed areas?

If yes, describe:

NA Yes $\square$ No

Work Halted? NA Yes $\square$ No $\square$

If yes, describe:

Notifications:

Date Contacted:

Contact Method:

| E-mail $\square$ Phone $\square$ Official correspondence, CCN\#:

$\begin{array}{llll}\text { Cultural Materials Observed? } & \text { Yes } \mathrm{X} \text { No }\end{array}$

If yes, describe: $\quad$ Thin scatter of lithic debitage- with occasional dense concentrations that include firecracked rock

Cultural Materials Collected? NA Yes $\square$ No

If yes, describe:

General Comments: This site has endured significant impact from historic grazing, water control activity (headgates) vehicular traffic and power line construction.

Recommendations: Occasional opportunistic monitoring

GPS Coordinates collected?

Yes $\square$ No $\mathrm{X}$

If yes, describe (datum, coordinates):

Attach additional documentation, as warranted (photos, profiles, etc.) $\quad$ Yes $\square$ No $\quad$ X If yes, describe: 
Monitor Number: BRP-09-01

Monitor Name: $\quad$ B. R. Pace, H. K. Gilbert

Monitor Date(s): $\quad$ October 14, 2008

Project:

Site Name/Number:

T-25 Road Improvements

Reason for Monitoring: 10-BM-109

Revisits to previously recorded sites in the area of potential effect for road improvements along the Power Line Road (T-25) between the Materials and Fuels Complex and Critical Infrastructure Test Range Complex.

Findings:

\begin{tabular}{|l|l|}
\hline Type 1 & $\mathrm{x}$ \\
\hline
\end{tabular}

Type 2

Type 3

Type 4

Impact Agent(s): $\quad$ Site has been impacted by a 2008 range fire and subsequent erosion.

Significance of Impact: Not significant. Site appears essentially the same as described in the 1985 site form and survey report.

Did disturbance or impact extend into undisturbed areas?

Yes No $\square$ No

If yes, describe: Some minor post-fire soil movement is currently taking place and may have covered some artifacts. However, this does not appear to have significantly changed the overall character or visibility of this site.

Work Halted?

If yes, describe: N/A

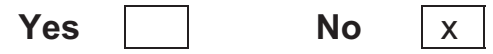

Notifications: $\quad$ None required under Type 1 Finding.

Date Contacted: N/A

Contact Method: $\mid$ E-mail $\quad \square$ Phone $\longleftarrow$ Official correspondence, CCN\#:

Cultural Materials Observed? Yes $\mathrm{x}$ No $\quad$

If yes, describe: The surface inventory appears similar to that reported in the 1985 survey report.

Approximately 60 flakes are present including obsidian, fine-grained basalt, quartzite, and grey ignimbrite. A few flakes are showing up on the south side of the road now

(10 meters from road), where fire has removed all vegetation. Deep sand is accumulating on north side of the road and is probably covering additional artifacts. Closest artifacts to the road on the north are 4-8 meters away. A knife-like biface fragment of obsidian, biface tip of grey ignimbrite, multicolored chalcedony retouched flake, and caramel chalcedony steep end scraper were observed. "Road" originally noted in area is probably a natural drainage channel.

Cultural Materials Collected? Yes $\square$ No $x$ If yes, describe: No collection.

General Comments: Artifacts are located on both sides of the road, directly within the area of potential effect. However, materials are definitely concentrated to the north. Aeolian sands are also accumulating on this side of the road and probably covering additional artifacts. Pole \# 75 is just to the west.

Recommendations: If disturbance can be restricted to south side of road and cultural deposits to the north can be avoided, impacts should not be adverse. However, soil disturbance should be monitored as work is completed.

GPS Coordinates collected?

Yes $\mathrm{x}$

No

If yes, describe (datum, coordinates):

Attach additional documentation, as warranted (photos, profiles, etc.) $\quad$ Yes $\quad x \quad$ No $\square$ If yes, describe: Photos of site area, knife fragment, biface tip, scraper, and retouched flake. 
Monitor Number: BRP-09-02

Monitor Name:

Monitor Date(s):

B. R. Pace, H. K. Gilbert

October 7, 2008

Project:

Site Name/Number:

T-25 Road Improvements

Reason for Monitoring: 10-BM-110

Revisits to previously recorded sites in the area of potential effect for road improvements along the Power Line Road (T-25) between the Materials and Fuels Complex and Critical Infrastructure Test Range Complex.

Findings:

\begin{tabular}{|l|l|}
\hline Type 1 & $\mathrm{x}$ \\
\hline
\end{tabular}

Type 2

Type 3

Type 4

Impact Agent(s): $\quad$ Site has been impacted by range fires and erosion over the past decade.

Significance of Impact: Not significant. Fires and subsequent erosion do not appear to have adversely impacted the site. It appears essentially the same as described in the 1985 site form and survey report.

Did disturbance or impact extend into undisturbed areas?

Yes $\square$ No $\mathrm{x}$

If yes, describe: Some minor post-fire soil movement may have taken place but it does not appear to have significantly altered the overall character or visibility of this site.

Work Halted? Yes

No $x$

If yes, describe: N/A

Notifications: $\quad$ None required under Type 1 Finding.

Date Contacted: N/A

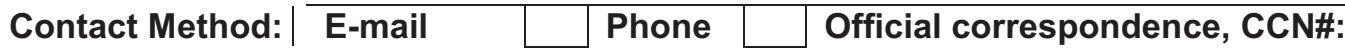

Cultural Materials Observed? Yes $x$ No

If yes, describe: The surface inventory appears similar to that reported in the 1985 survey report. Approximately 50 flakes are present, dominated by obsidian but one pretty lime green chert flake noted as well. A pile of larger flakes appears to be the result of artifact collectors. Nearly all of the artifacts are on the west side of the road $(\sim 32$ meters from road), but one retouched flake was observed on the east side only $\sim 2$ meters from the road. Small rock datum from original survey/recording was re-identified.

\section{Cultural Materials Collected? Yes $\square$ No $\mathrm{x}$}

If yes, describe: No collection.

General Comments: Artifacts are located on both sides of the road, directly within the area of potential effect. However, materials are definitely concentrated to the west near Pole \# 121.

Recommendations: If disturbance can be restricted to east side of road and cultural deposits to the west can be avoided, impacts should not be adverse. However, soil disturbance should be monitored as work is completed.

GPS Coordinates collected?

Yes $\mathrm{x}$

No

If yes, describe (datum, coordinates):

Attach additional documentation, as warranted (photos, profiles, etc.)

Yes

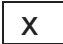

No

If yes, describe: Photos of site area. 
Monitor Number: BRP-09-03

Monitor Name: $\quad$ B. R. Pace, H. K. Gilbert

Monitor Date(s): $\quad$ October 7, 2008

Project:

Site Name/Number:

T-25 Road Improvements

Reason for Monitoring:

10-BM-112

Revisits to previously recorded sites in the area of potential effect for road improvements along the Power Line Road (T-25) between the Materials and Fuels Complex and Critical Infrastructure Test Range Complex.

Findings:

\begin{tabular}{|l|l|}
\hline Type 1 & $\mathrm{x}$ \\
\hline
\end{tabular}

Type 2

Type 3

Type 4

Impact Agent(s): $\quad$ Site has been impacted by range fires and erosion over the past decade.

Significance of Impact: Not significant. Fires and subsequent erosion do not appear to have adversely impacted the site. It appears essentially the same as described in the 1985 site form and survey report.

Did disturbance or impact extend into undisturbed areas?

Yes No $\square$ No

If yes, describe: Some minor post-fire soil movement is currently taking place and may have covered some artifacts. However, this does not appear to have significantly changed the overall character or visibility of this site.

Work Halted? Yes

No $x$

If yes, describe: N/A

Notifications: $\quad$ None required under Type 1 Finding.

Date Contacted: N/A

Contact Method: $\mid$\begin{tabular}{l|l|l|l|l}
\hline E-mail & & Phone & & Official correspondence, CCN\#:
\end{tabular}

Cultural Materials Observed? Yes $\mathrm{x}$ No

If yes, describe: The surface inventory appears similar to that reported in the 1985 survey report but no evidence of shovel tests in 1988 is apparent. Approximately 15 flakes are present, including obsidian, fine-grained basalt, and chalcedony. Burned bone fragments that appear to be cultural are also associated with the flakes and one crude biface fragment of obsidian was noted. All artifacts observed at this site are east of the road, $\sim 1-2$ meters away. Soils are deep and ryegrass dominates the vegetation community, so activities may be associated with playa resources.

Cultural Materials Collected? Yes $\square$ No $\mathrm{x}$ If yes, describe: No collection.

General Comments: Artifacts are currently restricted to an area more than 8 meters from the east side of the road near Pole \# 119. No subsurface cultural deposits were found during test excavations at this site in 1988. No current evidence of the previous excavations was observed.

Recommendations: If disturbance can be restricted to west side of road and cultural deposits to the east can be avoided, impacts should not be adverse. However, soil disturbance should be monitored as work is completed.

GPS Coordinates collected?

Yes $\mathrm{x}$

No

If yes, describe (datum, coordinates):

Attach additional documentation, as warranted (photos, profiles, etc.)

Yes

If yes, describe: $\quad$ Photos of site area. 
Monitor Number: BRP-09-04

Monitor Name: $\quad$ B. R. Pace, H. K. Gilbert

Monitor Date(s): $\quad$ October 23, 2008

Project:

Site Name/Number:

T-25 Road Improvements

Reason for Monitoring: Revisits to previously recorded sites in the area of potential effect for road improvements along the Power Line Road (T-25) between the Materials and Fuels Complex and Critical Infrastructure Test Range Complex.

Findings:

\begin{tabular}{|l|l|}
\hline Type 1 & $\mathrm{x}$ \\
\hline
\end{tabular}

Type 2

Type 3

Type 4

Impact Agent(s): $\quad$ Site has been impacted by range fires and erosion over the past decade.

Significance of Impact: Not significant. Fires and subsequent erosion do not appear to have adversely impacted the site. It appears essentially the same as described in the 1985 site form and survey report.

Did disturbance or impact extend into undisturbed areas?

Yes No $\square$ No

If yes, describe: Some minor post-fire soil movement is currently taking place and may have covered some artifacts. However, this does not appear to have significantly changed the overall character or visibility of this site.

Work Halted? Yes

No $x$

If yes, describe: N/A

Notifications: $\quad$ None required under Type 1 Finding.

Date Contacted: N/A

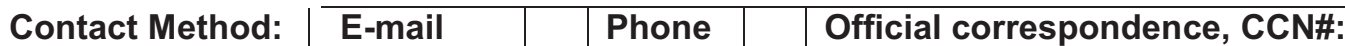

Cultural Materials Observed? Yes $\mathrm{x}$ No

If yes, describe: The surface inventory appears similar to that reported in the 1985 survey report. Approximately 30 flakes are present. Obsidian is dominant, but a few fragments of chalcedony are present as well. One small fragment of fire-cracked river rock was noted. No new chipped stone tools were observed. All artifacts are north of the road, 7 meters or more. The fiber optic cable that runs through the area is between the flakes and the road, very close to the road.

Cultural Materials Collected? Yes $\square$ No $\mathrm{x}$ If yes, describe: No collection.

General Comments: $\quad$ Artifacts are currently restricted to the north side of the road near Pole \# 102.

Recommendations: If disturbance can be restricted to south side of road and cultural deposits to the north can be avoided, impacts should not be adverse. However, soil disturbance should be monitored as work is completed.

GPS Coordinates collected?

Yes $\mathrm{x}$

No

If yes, describe (datum, coordinates):

Attach additional documentation, as warranted (photos, profiles, etc.)

Yes

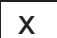

No

If yes, describe: $\quad$ Photos of site area. 
Monitor Number: BRP-09-05

Monitor Name: $\quad$ B. R. Pace, H. K. Gilbert

Monitor Date(s): $\quad$ October 14, 2008

Project:

Site Name/Number:

T-25 Road Improvements

Reason for Monitoring: Revisits to previously recorded sites in the area of potential effect for road improvements along the Power Line Road (T-25) between the Materials and Fuels Complex and Critical Infrastructure Test Range Complex.

Findings:

\begin{tabular}{|l|l|}
\hline Type 1 & $\mathrm{x}$ \\
\hline
\end{tabular}

Type 2

Type 3

Type 4

Impact Agent(s): $\quad$ Site has been impacted by range fires and erosion over the past decade.

Significance of Impact: Not significant. Fires and subsequent erosion do not appear to have adversely impacted the site. It appears essentially the same as described in the 1985 site form and survey report.

Did disturbance or impact extend into undisturbed areas?

Yes $\square$ No $x$

If yes, describe: Some minor post-fire soil movement is currently taking place and may have covered some artifacts. However, this does not appear to have significantly changed the overall character or visibility of this site.

Work Halted? Yes

No $x$

If yes, describe: N/A

Notifications: $\quad$ None required under Type 1 Finding.

Date Contacted: N/A

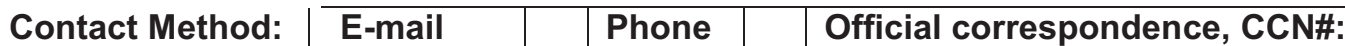

Cultural Materials Observed? Yes $\mathrm{x}$ No

If yes, describe: The surface inventory appears similar to that reported in the 1985 survey report. Approximately 30 flakes are present. Obsidian is dominant, but a few fragments of chalcedony are present as well. All artifacts are north of the road, 9 meters or more.

Cultural Materials Collected?

Yes

No $x$

If yes, describe: No collection.

General Comments: Artifacts are currently restricted to the north side of the road near Pole \# 105.

Recommendations: If disturbance can be restricted to south side of road and cultural deposits to the north can be avoided, impacts should not be adverse. However, soil disturbance should be monitored as work is completed.

GPS Coordinates collected?

Yes $x \quad$ No

If yes, describe (datum, coordinates):

Attach additional documentation, as warranted (photos, profiles, etc.)

Yes $x$

No

If yes, describe: Photos of site area. 
Monitor Number: BRP-09-06

Monitor Name: $\quad$ B. R. Pace, H. K. Gilbert

Monitor Date(s): $\quad$ October 14, 2008

Project:

Site Name/Number:

T-25 Road Improvements

Reason for Monitoring: 10-BM-118

Revisits to previously recorded sites in the area of potential effect for road improvements along the Power Line Road (T-25) between the Materials and Fuels Complex and Critical Infrastructure Test Range Complex.

Findings:

\begin{tabular}{|l|l|}
\hline Type 1 & $\mathrm{x}$ \\
\hline
\end{tabular}

Type 2

Type 3

Type 4

Impact Agent(s): $\quad$ Site has been impacted by range fires and erosion over the past decade.

Significance of Impact: Not significant. Fires and subsequent erosion do not appear to have adversely impacted the site. It appears essentially the same as described in the 1985 site form and survey report.

Did disturbance or impact extend into undisturbed areas?

Yes No $\square$ No

If yes, describe: Some minor post-fire soil movement is currently taking place and may have covered some artifacts. However, this does not appear to have significantly changed the overall character or visibility of this site.

Work Halted? Yes No $x$

If yes, describe: N/A

Notifications: $\quad$ None required under Type 1 Finding.

Date Contacted: N/A

Contact Method: $\mid$\begin{tabular}{l|l|l|l|l}
\hline E-mail & & Phone & & Official correspondence, CCN\#:
\end{tabular}

Cultural Materials Observed? Yes $x$ No

If yes, describe: The surface inventory appears similar to that reported in the 1985 survey report, but there is no evidence of 1988 shovel tests. Approximately 15 flakes are present, with many different types of material represented (obsidian, chalcedony, fine-grained basalt). No new chipped stone tools were observed. Artifacts are on both sides of the road within 3 meters. However, the densest concentration is to the south.
Cultural Materials Collected?
Yes
No $x$

If yes, describe: No collection.

General Comments: Artifacts are currently located within 3 meters of either side of the road, but are concentrated to the south. Pole \#105 is nearby. Test excavations in 1988 revealed no subsurface cultural deposits at this location. No evidence of these previous excavations was observed.

Recommendations: Subsurface cultural materials are unlikely at this location and no additional excavations are recommended. However, soil disturbance should be monitored as work is completed.

GPS Coordinates collected?

Yes $x$

No If yes, describe (datum, coordinates):

Attach additional documentation, as warranted (photos, profiles, etc.) Yes If yes, describe: $\quad$ Photos of site area. 
Monitor Number: $\quad$ BRP-09-07

Monitor Name: $\quad$ B. R. Pace, H. K. Gilbert

Monitor Date(s): $\quad$ October 6, 2008

Project:

Site Name/Number:

T-25 Road Improvements

Reason for Monitoring: 10-BT-1049

Revisits to previously recorded sites in the area of potential effect for road improvements along the Power Line Road (T-25) between the Materials and Fuels Complex and Critical Infrastructure Test Range Complex.

Findings:

\begin{tabular}{|l|l|}
\hline Type 1 & $\mathrm{x}$ \\
\hline
\end{tabular}

Type 2

Type 3

Type 4

Impact Agent(s): $\quad$ Site has been impacted by range fires and erosion over the past decade.

Significance of Impact: Not significant. Surface artifacts have been covered by aeolian sand eroded from a nearby range fire that burned in 2008.

Did disturbance or impact extend into undisturbed areas?

Yes No $\square$ No

If yes, describe: Post-fire soil movement has resulted in a deep accumulation of sand over this site area. Nearly all of the artifacts noted in 1985 have been covered.

Work Halted?

If yes, describe: N/A

Notifications: $\quad$ None required under Type 1 Finding.

Date Contacted: N/A

Contact Method: | E-mail $\square$ Phone $\square$ Official correspondence, CCN\#:

Cultural Materials Observed? Yes $\mathrm{x}$ No $\square$

If yes, describe: Nearly all of the artifacts originally noted at this site are buried under a deep accumulation of aeolian sand. Only two flakes of the twelve flakes originally recorded were observed, one on each side of the road.

Cultural Materials Collected?

Yes $\square$ No $x$

If yes, describe: No collection.

General Comments: Artifacts are located on both sides of the road west of Pole \# 77, but are very sparse. Aeolian sands are accumulating rapidly in the area and may be covering additional artifacts.

Recommendations: If ground disturbance is limited in this area and all activities are monitored, impacts should not be adverse.

GPS Coordinates collected?

Yes $x$ No

If yes, describe (datum, coordinates):

Attach additional documentation, as warranted (photos, profiles, etc.) Yes $x$ No If yes, describe: $\quad$ Photos of site area. 
Monitor Number: BRP-09-08

Monitor Name: $\quad$ B. R. Pace, H. K. Gilbert

Monitor Date(s): $\quad$ October 6, 2008

Project:

Site Name/Number:

T-25 Road Improvements

Reason for Monitoring: 10-BT-1052

Revisits to previously recorded sites in the area of potential effect for road improvements along the Power Line Road (T-25) between the Materials and Fuels Complex and Critical Infrastructure Test Range Complex.

Findings:

\begin{tabular}{|l|l|}
\hline Type 1 & $\mathrm{x}$ \\
\hline
\end{tabular}

Type 2

Type 3

Type 4

Impact Agent(s): Site has been impacted by range fires and erosion over the past decade.

Significance of Impact: Not significant. Fires and subsequent erosion do not appear to have adversely impacted the site. It appears essentially the same as described in the 1985 site form and survey report.

Did disturbance or impact extend into undisturbed areas?

Yes $\square$ No $x$

If yes, describe: Some minor post-fire soil movement is currently taking place and may have covered some artifacts. However, this does not appear to have significantly changed the overall character or visibility of this site.

Work Halted? Yes

No $x$

If yes, describe: N/A

Notifications: $\quad$ None required under Type 1 Finding.

Date Contacted: N/A

Contact Method: $\mid$\begin{tabular}{l|l|l|l|l}
\hline E-mail & & Phone & & Official correspondence, CCN\#:
\end{tabular}

Cultural Materials Observed? Yes $x$ No

If yes, describe: The surface inventory appears similar to that reported in the 1985 survey report, but there is no evidence of $1 \times 2$ meter test units excavated in 1988. Flakes were observed in the road and on both sides of it. Approximately 75 flakes are present including obsidian, fine-grained basalt, and a variety of silicates. Artifacts noted in 2005 (Desert Side-notched points, shell fragment) were not re-identified. Artifacts that were noted include a chalcedony scraper, obsidian stemmed-indented base point, nondiagnostic point fragment of obsidian, and a utilized flake.

\section{Cultural Materials Collected? \\ Yes \\ No $x$}

If yes, describe: No collection.

General Comments: Artifacts are currently located on both sides of the road around Pole \#85, directly within the area of potential effect for road improvements. Test excavations conducted in 1988 revealed subsurface cultural deposits, including a buried fire hearth within this site area. However, no evidence of these pits is currently visible in the area. In addition, none of the 1988 test units were located in the current area of potential effect for road improvements

Recommendations: Additional test excavations should be completed in advance of ground disturbance. Work activities should also be monitored for new finds.

GPS Coordinates collected?

Yes $\mathrm{x}$

No

If yes, describe (datum, coordinates):

Attach additional documentation, as warranted (photos, profiles, etc.)

Yes

$\mathrm{x}$

No

If yes, describe: $\quad$ Photos of site area, scraper, point fragment, and biface fragment. 
Monitor Number: BRP-09-09

Monitor Name:

Monitor Date(s):

B. R. Pace, H. K. Gilbert

October 14, 2008

Project:

Site Name/Number:

T-25 Road Improvements

Reason for Monitoring: 10-BT-1053

Revisits to previously recorded sites in the area of potential effect for road improvements along the Power Line Road (T-25) between the Materials and Fuels Complex and Critical Infrastructure Test Range Complex.

\begin{tabular}{|l|l|l|l|l|}
\hline Findings: & Type 1 & $\mathrm{x}$
\end{tabular}$\quad$\begin{tabular}{|l|l|l|}
\hline Type 2 & Type 3 \\
\hline
\end{tabular}

Impact Agent(s): $\quad$ Site has been impacted by range fires and fire-fighting activities (fire breaks, off-road vehicle use and equipment staging).

Significance of Impact: $\quad$ Not significant. Fires, erosion, and fire-fighting activities have impacted the site but undisturbed cultural deposits appear to remain.

\begin{tabular}{lll|l|l|} 
Did disturbance or impact extend into undisturbed areas? & Yes & No & $\mathrm{x}$
\end{tabular}

If yes, describe: Some minor post-fire soil movement is currently taking place and may have covered some artifacts. However, this does not appear to have significantly changed the overall character or visibility of this site. Fire-breaks and off-road vehicle use have caused additional impacts in narrow zones passing through the site area.

Work Halted? Yes $\square$ No $x$

If yes, describe: N/A

Notifications: $\quad$ None required under Type 1 Finding.

Date Contacted: N/A

Contact Method: | E-mail $\quad \square$ Phone $\square$ Official correspondence, CCN\#:

$\begin{array}{llll}\text { Cultural Materials Observed? } & \text { Yes } x \text { No }\end{array}$

If yes, describe: The surface inventory appears similar to that reported in the 1985 survey report. Approximately 35 flakes were observed, most far to the south of the road. However, one flake was observed in an ashy area only 10 meters from the road. Fire breaks cut through the area and artifacts are exposed within them, including two small pressure flakes about 20 meters from the road and many more at further distances. These artifacts suggest that shallowly buried cultural materials are probably present in the area. One biface tip was also observed in the fire break.

\section{Cultural Materials Collected? Yes $\square$ No $\mathrm{X}$}

If yes, describe: No collection.

General Comments: Most artifacts are located far to the south of the road between Poles \#81 and 82, outside the area of potential effect for road improvements. However, flakes are located approximately 10 meters south of the road in an ashy area where sand is accumulating and approximately 20 meters south of the road in a fire break.

Recommendations: If disturbance can be restricted to the north side of road and cultural deposits to the south remain undisturbed, impacts should not be adverse. However, monitoring should be conducted as work is completed.

GPS Coordinates collected? If yes, describe (datum, coordinates):

Attach additional documentation, as warranted (photos, profiles, etc.) If yes, describe:
Yes $x$ No

No $\square$ 
Monitor Number: BRP-09-10

Monitor Name: $\quad$ B. R. Pace, H. K. Gilbert

Monitor Date(s): $\quad$ October 16, 2008

Project:

Site Name/Number:

T-25 Road Improvements

Reason for Monitoring: 10-BT-1059

Revisits to previously recorded sites in the area of potential effect for road improvements along the Power Line Road (T-25) between the Materials and Fuels Complex and Critical Infrastructure Test Range Complex.
Findings:
\begin{tabular}{|l|l|}
\hline Type 1 & $\mathrm{x}$ \\
\hline
\end{tabular}
Type 2
Type 3
Type 4
Impact Agent(s): $\quad$ Site appears undisturbed and has not been burned in the last three decades.
Significance of Impact: Not significant. Site appears to be essentially the same as described in the 1985 site form and survey report.

Did disturbance or impact extend into undisturbed areas?

Yes $\square$ No $\mathrm{x}$

If yes, describe: Aside from impacts associated with the existing road and power line, this site appears to be undisturbed. No fires have burned through this area in historic times.

Work Halted?

If yes, describe: N/A

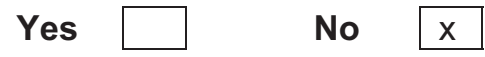

Notifications: $\quad$ None required under Type 1 Finding.

Date Contacted: N/A

Contact Method: | E-mail $\square$ Phone $\square$ Official correspondence, CCN\#:

Cultural Materials Observed? Yes $\mathrm{x}$ No $\square$

If yes, describe: The surface inventory appears similar to that reported in the 1985 survey report, but there is no evidence remaining of $1 \times 2$ meter test pits excavated here in 1988. A chaining pin and the rebar stake marking the main site datum were re-identified. Flakes were observed in the road and on both sides of it. Approximately 20 flakes are present, including obsidian and a variety of silicates. Tools included an Elko Cornernotched point made of red chert and a crude chalcedony biface fragment.

Cultural Materials Collected? Yes $\square$ No $\mathrm{x}$

If yes, describe: No collection.

General Comments: Artifacts are located on both sides of the road, between Poles \# 64 and 65, directly within the area of potential effect for road improvements. Although 1988 test excavations did not reveal subsurface cultural materials, no test units were placed within the current area of potential effect.

Recommendations: Additional test excavations should be completed in advance of ground disturbance. In addition, monitoring should be conducted as work is completed.

GPS Coordinates collected?

Yes $\mathrm{x}$

No

If yes, describe (datum, coordinates):

Attach additional documentation, as warranted (photos, profiles, etc.) If yes, describe: Photos of site area and Elko Corner-notched point fragment.

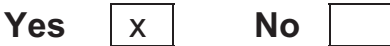


Monitor Number: BRP-09-11

Monitor Name: $\quad$ B. R. Pace, H. K. Gilbert

Monitor Date(s): $\quad$ October 14, 2008

Project:

Site Name/Number:

T-25 Road Improvements

Reason for Monitoring: 10-BT-1062

Revisits to previously recorded sites in the area of potential effect for road improvements along the Power Line Road (T-25) between the Materials and Fuels Complex and Critical Infrastructure Test Range Complex.

Findings:

\begin{tabular}{|l|l|}
\hline Type 1 & $\mathrm{x}$ \\
\hline
\end{tabular}

Type 2

Type 3

Type 4

Impact Agent(s): $\quad$ Site has been impacted by range fires, erosion, and soil deposition.

Significance of Impact: Not significant. Although more artifacts are now visible, the site appears to be essentially the same as described in the 1985 site form and survey report.

Did disturbance or impact extend into undisturbed areas?

Yes

No $x$

If yes, describe: Some minor post-fire soil movement is currently taking place and may be covering additional artifacts.

Work Halted?

Yes

No $\mathrm{x}$

If yes, describe: N/A

Notifications: $\quad$ None required under Type 1 Finding.

Date Contacted: N/A

Contact Method: | E-mail $\quad \square$ Phone $\quad \square$ Official correspondence, CCN\#:

Cultural Materials Observed? Yes $\mathrm{x}$ No $\square$

If yes, describe: The surface inventory appears similar to that reported in the 1985 survey report, although more flakes are visible now since the fire has removed all of the vegetation. Approximately 100 flakes of obsidian and various silicates were observed. Most are north of the road, but a concentration is present to the south of the road as well.

Sands are also beginning to accumulate in low areas, possibly hiding additional artifacts. Chipped stone tools observed on the surface included an Elko Cornernotched point fragment, Humboldt Lanceolate point fragment, a biface fragment, and a quartzite scraper.

Cultural Materials Collected? Yes $\square$ No $\mathrm{X}$

If yes, describe: No collection.

General Comments: Artifacts are located on both sides of the road, between Poles \# 69 and 70, directly within the area of potential effect for road improvements.

Recommendations: If ground disturbance is limited in this area and all activities are monitored, impacts should not be adverse. However, additional investigations, possibly including test excavations will be necessary if road improvements will extend more than a few meters from the existing road bed.

GPS Coordinates collected?

Yes $x$

No If yes, describe (datum, coordinates):

Attach additional documentation, as warranted (photos, profiles, etc.) $\quad$ Yes $x$ No If yes, describe: $\quad$ Photos of site area, Elko point, Humboldt point, scraper, and biface fragment. 
Monitor Number: BRP-09-12

Monitor Name: $\quad$ B. R. Pace, H. K. Gilbert

Monitor Date(s): $\quad$ October 23, 2008

Project:

Site Name/Number:

T-25 Road Improvements

Reason for Monitoring: Revisits to previously recorded sites in the area of potential effect for road improvements along the Power Line Road (T-25) between the Materials and Fuels Complex and Critical Infrastructure Test Range Complex.

Findings:

\begin{tabular}{|l|l|}
\hline Type 1 & $\mathrm{x}$ \\
\hline
\end{tabular}

Type 2

Type 3

Type 4

Impact Agent(s): $\quad$ Site has been impacted by range fires and erosion over the past decade.

Significance of Impact: Not significant. Fires and subsequent erosion do not appear to have adversely impacted the site. It appears essentially the same as described in the 1985 site form and survey report.

Did disturbance or impact extend into undisturbed areas?

Yes $\square$ No $\mathrm{x}$

If yes, describe: Some minor post-fire soil movement is currently taking place but it does not appear to have significantly changed the overall character or visibility of this site.

Work Halted? Yes

No $x$

If yes, describe: N/A

Notifications: $\quad$ None required under Type 1 Finding.

Date Contacted: N/A

Contact Method: | E-mail $\quad$ Phone $\quad$ Official correspondence, CCN\#:

Cultural Materials Observed? Yes $\mathrm{x}$ No $\square$

If yes, describe: The surface inventory appears similar to that reported in the 1985 survey report. Approximately 11 flakes were observed, all obsidian. No new chipped stone tools were observed. All artifacts are at least 50 meters east of the road.

Cultural Materials Collected?

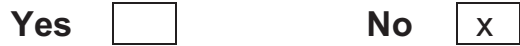

If yes, describe: No collection.

General Comments: Artifacts are restricted to the east side of the road and are outside the area of potential effect for road improvements, more than 50 meters away.

Recommendations: No additional investigations recommended.

GPS Coordinates collected?

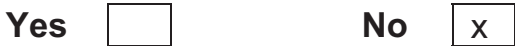

If yes, describe (datum, coordinates):

Attach additional documentation, as warranted (photos, profiles, etc.) Yes No $x$ If yes, describe: 
Monitor Number: BRP-09-13

Monitor Name: $\quad$ B. R. Pace, H. K. Gilbert

Monitor Date(s): $\quad$ October 6, 2008

Project:

Site Name/Number:

T-25 Road Improvements

Reason for Monitoring: 10-BT-1247

Revisits to previously recorded sites in the area of potential effect for road improvements along the Power Line Road (T-25) between the Materials and Fuels Complex and Critical Infrastructure Test Range Complex.

Findings:

\begin{tabular}{|l|l|}
\hline Type 1 & $\mathrm{x}$ \\
\hline
\end{tabular}

Type 2

Type 3

Type 4

Impact Agent(s): $\quad$ Site has been impacted by range fires and erosion over the past decade.

Significance of Impact: Not significant. Although more artifacts are now visible, the site appears to be essentially the same as described in the 1985 site form and survey report.

Did disturbance or impact extend into undisturbed areas?

Yes

No $x$

If yes, describe: Some minor post-fire soil movement is currently taking place and may be covering additional artifacts.

Work Halted?

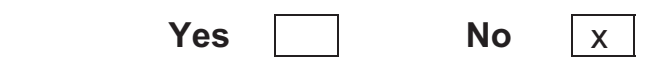

If yes, describe: N/A

Notifications: $\quad$ None required under Type 1 Finding.

Date Contacted: N/A

Contact Method: | E-mail $\square$ Phone $\square$ Official correspondence, CCN\#:

Cultural Materials Observed? Yes $\mathrm{x}$ No $\square$

If yes, describe: The surface inventory appears similar to that reported in the 1985 survey report, but there is no evidence of 1988 test excavations and fire-cracked rock reported originally in 1985 is no longer apparent on the surface. Approximately 25 flakes are present, dominated by obsidian. Two Elko Corner-notched point fragments observed in 2005 were also re-identified, as was the rebar stake marking the 1988 site datum. Artifacts are south of the road, approximately 27 meters.

Cultural Materials Collected?

Yes

No $x$

If yes, describe: No collection.

General Comments: Artifacts are restricted to the south side of the road around Poles \#84 and 85 but are at least 27 meters away. Buried cultural deposits were identified during test excavations at this location in 1988. Though no evidence of these test pits is apparent today, the potential for additional buried materials remains.

Recommendations: If ground disturbance is restricted to the north side of the road and cultural deposits located to the south are avoided, impacts should not be adverse. However, since buried cultural materials have been previously documented, monitoring should be conducted during any ground disturbance.

GPS Coordinates collected?

Yes $x$

No If yes, describe (datum, coordinates):

Attach additional documentation, as warranted (photos, profiles, etc.)

Yes

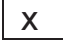

No

If yes, describe: Photos of site area and two Elko corner-notched points. 
Monitor Number: BRP-09-14

Monitor Name: $\quad$ B. R. Pace, H. K. Gilbert

Monitor Date(s): $\quad$ October 14, 2008

Project:

Site Name/Number:

T-25 Road Improvements

Reason for Monitoring: 10-BT-1063

Revisits to previously recorded sites in the area of potential effect for road improvements along the Power Line Road (T-25) between the Materials and Fuels Complex and Critical Infrastructure Test Range Complex.

Findings:

\begin{tabular}{|l|l|}
\hline Type 1 & $\mathrm{x}$ \\
\hline
\end{tabular}

Type 2

Type 3

Type 4

Impact Agent(s): $\quad$ Site has been impacted by range fires and erosion over the past decade.

Significance of Impact: Not significant. Although more artifacts are now visible, the site appears to be essentially the same as described in the 1985 site form and survey report.

Did disturbance or impact extend into undisturbed areas?

Yes

No $x$

If yes, describe: Some minor post-fire soil movement is currently taking place and may be covering additional artifacts.

Work Halted?

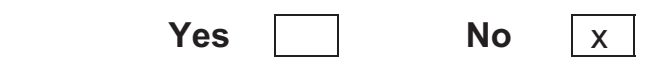

If yes, describe: N/A

Notifications: $\quad$ None required under Type 1 Finding.

Date Contacted: N/A

Contact Method: | E-mail $\square$ Phone $\square$ Official correspondence, CCN\#:

Cultural Materials Observed? Yes $\mathrm{x}$ No

If yes, describe: The surface inventory appears similar to that reported in the 1985 survey report, although more flakes are visible now since the fire has removed all of the vegetation.

Approximately 30 flakes of obsidian, various silicates, and grey ignimbrite were observed. All are south of the road, at least 48 meters from the road. However, sands are beginning to accumulate in low areas, possibly hiding additional artifacts. Chipped stone tools observed on the surface included one large notched point fragment.

\section{Cultural Materials Collected? \\ Yes \\ No $x$}

If yes, describe: No collection.

General Comments: Artifacts are restricted to the south side of the road in the vicinity of Pole \# 70 are at least 48 meters away.

Recommendations: If ground disturbance is limited in scope throughout this area and all activities are monitored, impacts should not be adverse. However, additional investigations possibly including test excavations will be necessary if road improvements will extend more than a few meters from the existing road bed.

GPS Coordinates collected?

Yes $x$

No

If yes, describe (datum, coordinates):

Attach additional documentation, as warranted (photos, profiles, etc.)

Yes

No If yes, describe: Photos of site area and large notched point fragment. 
Monitor Number: BRP-09-21

Monitor Name: $\quad$ B. R. Pace, J.B. Braun, H. K. Gilbert

Monitor Date(s): $\quad 6 / 30 / 09$

Project: $\quad$ BEA-09-05: Ordnance Surveys--Railcar Area

Site Name/Number: $\quad$ 10-BT-2050 (LMIT-96-51-04)

Reason for Monitoring: Assessment of potential impacts of ongoing ordnance surveys and cleanup, including cross-country geophysical surveys with ATV and cart.

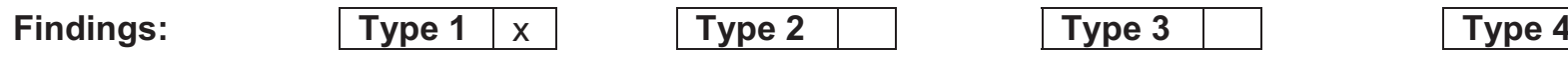

Impact Agent(s): $\quad$ No new impacts observed.

Significance of Impact: N/A

Did disturbance or impact extend into undisturbed areas? $\quad$ Yes $\quad$ No $\quad$ No

If yes, describe:

$\begin{array}{lll}\text { Work Halted? } & \text { Yes } & \\ & & \mathrm{x}\end{array}$

If yes, describe:

Notifications: N/A

Date Contacted:

Contact Method:| E-mail $\quad$ Phone $\quad \longrightarrow$ Official correspondence, CCN\#:

$\begin{array}{lllll}\text { Cultural Materials Observed? } & \text { Yes } & \mathrm{X} & \\ \end{array}$

If yes, describe: Artifact assemblage appeared similar to original recording with a dispersed scatter of approximately 50 larger obsidian flakes. No new artifacts were discovered.

Cultural Materials Collected?

Yes $\square$ No $x$

If yes, describe: No collection.

General Comments: Site appears to be essentially unchanged from original recording. GPS locational information collected for site boundary.

Recommendations: $\quad$ Extensive ground disturbance during future cleanup activities should be avoided to protect undisturbed subsurface cultural deposits. Additional data collection prior to cleanup may be necessary. Geophysical data (magnetometer) collected from this location should be analyzed for value in the archaeological investigation.

GPS Coordinates collected?

Yes $\mathrm{x}$ No

If yes, describe (datum, coordinates):

Attach additional documentation, as warranted (photos, profiles, etc.) Yes No $x$ If yes, describe: 
Monitor Number: $\quad$ BRP-09-22

Monitor Name: $\quad$ B. R. Pace, J. B. Braun, H. K. Gilbert

Monitor Date(s): $\quad 6 / 30 / 09$

Project: $\quad$ BEA-09-05: Ordnance Surveys--Railcar Area

Site Name/Number: $\quad$ 10-BT-2051 (LMIT-96-51-05)

Reason for Monitoring: Assessment of potential impacts of ongoing ordnance surveys and cleanup, including cross-country geophysical surveys with ATV and cart.

\begin{tabular}{l|l|l|l|l|}
\hline Findings: & Type 1 & $\mathrm{x}$ & Type 2 & Type 3 \\
\hline
\end{tabular}

Impact Agent(s): $\quad$ No new impacts observed.

Significance of Impact: N/A

\begin{tabular}{ll|l|l|} 
Did disturbance or impact extend into undisturbed areas? & Yes & No & $\mathrm{x}$
\end{tabular}

If yes, describe:

$\begin{array}{llll}\text { Work Halted? } & \text { Yes } \\ & & \end{array}$

If yes, describe:

Notifications: N/A

Date Contacted:

Contact Method:| E-mail $\quad \square$ Phone $\square$ Official correspondence, CCN\#:

Cultural Materials Observed? Yes $\mathrm{X}$ No $\square$

If yes, describe: Artifact assemblage appeared similar to original recording with a dispersed scatter of approximately 40 flakes and widely scattered fragments of fire-cracked rock. Original site datum was relocated and a core noted but not collected during the original recording was also observed.

Cultural Materials Collected?

Yes $\square$ No $x$

If yes, describe: No collection.

General Comments: Site appears to be essentially unchanged from original recording. GPS locational information collected for site boundary as well as original map datum.

Recommendations: Extensive ground disturbance during future cleanup activities should be avoided to protect undisturbed subsurface cultural deposits and features (e.g. fire hearths). Additional data collection prior to cleanup may be necessary. Geophysical data (magnetometer) collected from this location should be analyzed for value in the archaeological investigation.

GPS Coordinates collected?

Yes $x$

No

If yes, describe (datum, coordinates):

Attach additional documentation, as warranted (photos, profiles, etc.)

Yes

No $x$ If yes, describe: 
Monitor Number: $\quad$ BRP-09-23

Monitor Name:

Monitor Date(s):

B. R. Pace, J. B. Braun, H. K. Gilbert

$6 / 30 / 09$

Project:

BEA-09-05: Ordnance Surveys--Railcar Area

Site Name/Number: 10-BT-2052 (LMIT-96-51-06)

Reason for Monitoring: Assessment of potential impacts of ongoing ordnance surveys and cleanup, including cross-country geophysical surveys with ATV and cart.

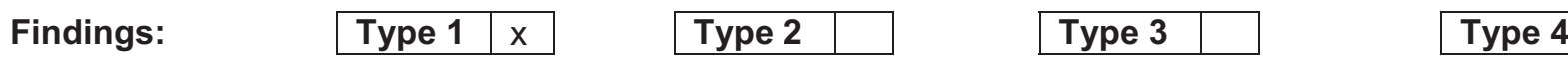

Impact Agent(s): $\quad$ No new impacts observed.

Significance of Impact: N/A

Did disturbance or impact extend into undisturbed areas?

If yes, describe:

\begin{tabular}{llll} 
Work Halted? & Yes $\square$ No & $\mathrm{x}$ \\
\hline
\end{tabular}

If yes, describe:

Notifications: N/A

Date Contacted:

Contact Method: | E-mail Phone Official correspondence, CCN\#:

Cultural Materials Observed? Yes $\mathrm{x}$ No $\square$

If yes, describe: Artifact assemblage appeared similar to original recording with a concentrated scatter of nearly 100 flakes and small activity areas marked by fire-cracked rock. All materials are concentrated on the lowest terrace along a pronounced but abandoned channel. Original site datum (yellow-capped rebar stake) was relocated. New artifacts observed included a Cottonwood Triangular point and two small biface fragments.

Cultural Materials Collected?

If yes, describe: No collection.

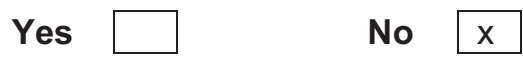

General Comments: Range fire in 2003 (?) has removed larger shrub vegetation, making artifacts easier to see at this site. Debitage, fire-cracked rock, and chipped stone tool inventories are expanded as a result. GPS locational information collected for site boundary as well as datum and new artifacts.

Recommendations: Extensive ground disturbance during future cleanup activities should be avoided to protect undisturbed subsurface cultural deposits and features (e.g. fire hearths). Additional data collection prior to cleanup may be necessary. Geophysical data (magnetometer) collected from this location should be analyzed for value in the archaeological investigation.

GPS Coordinates collected?

Yes $\mathrm{x}$

No If yes, describe (datum, coordinates):

Attach additional documentation, as warranted (photos, profiles, etc.) Yes If yes, describe: Photos of newly discovered artifacts on file. 
Monitor Number: BRP-09-24

Monitor Name:

Monitor Date(s):

B. R. Pace, J. B. Braun, H. K. Gilbert

$6 / 30 / 09$

Project:

BEA-09-05: Ordnance Surveys--Railcar Area

Site Name/Number: 10-BT-2053 (LMIT-96-51-07)

Reason for Monitoring: Assessment of potential impacts of ongoing ordnance surveys and cleanup, including cross-country geophysical surveys with ATV and cart.

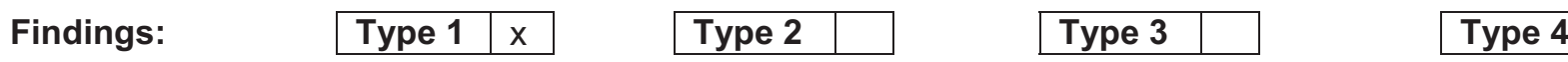

Impact Agent(s): $\quad$ No new impacts observed.

Significance of Impact: N/A

Did disturbance or impact extend into undisturbed areas?

If yes, describe:

Work Halted?

If yes, describe:

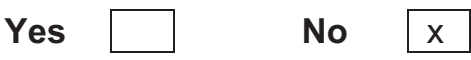

Notifications: N/A

Date Contacted:

Contact Method: | E-mail Phone Official correspondence, CCN\#:

$\begin{array}{llll}\text { Cultural Materials Observed? } & \text { Yes } & x & \text { No }\end{array}$

If yes, describe: Artifact assemblage appeared similar to original recording with a dense and diverse scatter of several hundred flakes and small activity areas marked by fire-cracked rock, burned bone, pottery, scrapers, small arrow points, and many general utility biface fragments. Artifacts are concentrated on the lowest terrace along a pronounced but abandoned channel. New artifacts observed included another scatter of Intermountain Ware pottery, a scraper, four biface fragments, a Cottonwood Triangular point base and a Desert Side-notched point base.

Cultural Materials Collected? Yes $\square$ No $\mathrm{x}$

If yes, describe: No collection.

General Comments: Range fire in 2003 (?) has removed larger shrub vegetation, making artifacts easier to see at this site. Debitage, fire-cracked rock, and chipped stone tool inventories are expanded as a result. GPS locational information collected for site boundary as well as datum and new artifacts.

Recommendations: $\quad$ Extensive ground disturbance during future cleanup activities should be avoided to protect undisturbed subsurface cultural deposits and features (e.g. fire hearths). Additional data collection prior to cleanup may be necessary. Geophysical data (magnetometer) collected from this location should be analyzed for value in the archaeological investigation.

GPS Coordinates collected?

Yes $x$

No If yes, describe (datum, coordinates):

Attach additional documentation, as warranted (photos, profiles, etc.) Yes If yes, describe: Photos of newly discovered artifacts on file. 
Monitor Number: BRP-09-27

Monitor Name: $\quad$ B. R. Pace, H. K. Gilbert

Monitor Date(s): $\quad$ August 20, 2009

Project: $\quad$ National Security Test Range

Site Name/Number: $\quad$ 10-JF-88/Hellofasite

Reason for Monitoring: Routine surveillance of archaeological sites in vicinity of project

\begin{tabular}{l|l|l|l|l|}
\hline Findings: & Type 1 & Type 2 & Type 3 & Type 4 \\
\cline { 2 - 4 }
\end{tabular}

Impact Agent(s): $\quad$ No new impacts have occurred.

Significance of Impact: N/A

Did disturbance or impact extend into undisturbed areas?

If yes, describe:

$\begin{array}{llll}\text { Work Halted? } & \text { Yes } \\ & & \end{array}$

If yes, describe:

Notifications: N/A

Date Contacted:

Contact Method: $\mid$ E-mail $\quad \square$ Phone $\square$ Official correspondence, CCN\#:

Cultural Materials Observed? Yes $\mathrm{x}$ No $\square$

If yes, describe: In 1984 the site was named "Hellofasite" for the dense, diverse scatter of artifacts and unique rock walls recorded there.

Cultural Materials Collected? Yes $\square$ No $\mathrm{x}$

If yes, describe: No collection.

General Comments: Visual inspection of site and rock walls indicates no impact resulting from explosive testing. Surface artifacts appear undisturbed and the site does not appear to be subject to unauthorized visitation. Powerline repair has cause extensive soil disturbance but appears to be restricted to areas previously impacted adjacent to the poles.

Recommendations: $\quad$ Continue monitoring for impacts associated with the nearby Test Range as well as powerline maintenance/repair.

GPS Coordinates collected?

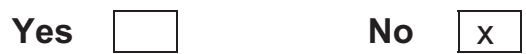

If yes, describe (datum, coordinates):

Attach additional documentation, as warranted (photos, profiles, etc.) Yes $\square$ No $\quad x$ If yes, describe: 
A: Historic Archaeological Sites 
Idaho National Laboratory Cultural Resource Management Office Field Monitoring Form

Monitor Number:

Monitor Name:

Monitor Date(s):

HKG-09-01

Hollie K. Gilbert and Julie B. Braun

$8 / 7 / 09$

Project:

Site Name/Number:

Routine Monitoring

Reason for Monitoring:

Lillie Wakefield Homestead/BEA-07-32-107

Findings:

\begin{tabular}{|l|l|}
\hline Type 1 & $\mathrm{x}$ \\
\hline
\end{tabular}

Type 2

Type 3

Type 4

Impact Agent(s): $\quad$ On going rodent activity

Significance of Impact: $\quad$ Large badger holes noted around and under cistern and foundation.

An abundance of halogeton was also noted in the area.

Did disturbance or impact extend into undisturbed areas?

Yes $\square$ No $\mathrm{x}$

If yes, describe:

Work Halted?

If yes, describe:

Notifications:

Date Contacted:

Contact Method:

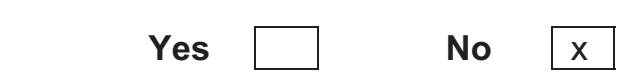

Cultural Materials

If yes, describe:

$$
\text { N/A }
$$

| E-mail $\square$ Phone $\square$ Official correspondence, CCN\#:

Observed? Yes $x$

Artifacts appear to be undisturbed.

No

One new artifact was noted; suspender hardware with a patent date of 7-14-1908.

Cultural Materials Collected?

Yes $\square$ No $x$

If yes, describe: No collection.

General Comments: $\quad$ Road T-16 has been heavily used in the past by ranchers and USGS personnel. From the abundance of weeds growing in the road bed, it appears that T-16 did not see much traffic this year.

Recommendations: None

GPS Coordinates collected?

Yes $\square$ No $x$

If yes, describe (datum, coordinates):

Attach additional documentation, as warranted (photos, profiles, etc.) $\quad$ Yes $\quad \square \quad$ No $\quad x$ If yes, describe: 
Idaho National Laboratory Cultural Resource Management Office

Field Monitoring Form

Monitor Number:

Monitor Name:

Monitor Date(s):

HKG-09-02

Hollie K. Gilbert and Julie B. Braun

$8 / 7 / 09$

Project:

Site Name/Number:

Routine Monitoring

Reason for Monitoring: $\quad$ Assessment of potential impacts of ongoing use of road T-16.

Findings:

\begin{tabular}{|l|l|}
\hline Type 1 & $x$ \\
\hline
\end{tabular}

Type 2

Type 3

Type 4

Impact Agent(s): $\quad$ None noted.

Significance of Impact: Halogeton was also noted in the area.

Did disturbance or impact extend into undisturbed areas?

If yes, describe:

Work Halted?

If yes, describe:

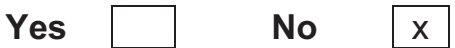

Notifications:

Date Contacted:

Contact Method:

Cultural Materials Observed?

Yes

No

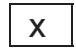

If yes, describe: $\quad$ Artifacts appear to be undisturbed.

Cultural Materials Collected? Yes $\square$ No $x$

If yes, describe: No collection.

General Comments: $\quad$ Road T-16 has been heavily used in the past by ranchers and USGS personnel. From the abundance of weeds growing in the road bed, it appears that T-16 did not see much traffic this year.

Recommendations: None

GPS Coordinates collected?

Yes $\square$ No $x$

If yes, describe (datum, coordinates):

Attach additional documentation, as warranted (photos, profiles, etc.)

Yes

No $x$

If yes, describe: 
Idaho National Laboratory Cultural Resource Management Office Field Monitoring Form

Monitor Number:

Monitor Name:

Monitor Date(s):

HKG-09-03

Hollie K. Gilbert and Julie B. Braun

$8 / 7 / 09$

Project:

Site Name/Number:

Routine Monitoring

Reason for Monitoring: $\quad$ Assessment of potential impacts of ongoing use of road T-16.

Findings:

\begin{tabular}{|l|l|}
\hline Type 1 & $\mathrm{x}$ \\
\hline
\end{tabular}

Type 2

Type 3

Type 4

Impact Agent(s): $\quad$ None noted.

Significance of Impact: N/A

Did disturbance or impact extend into undisturbed areas?

If yes, describe:

Work Halted?

If yes, describe:

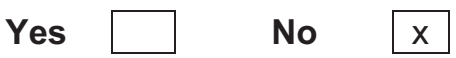

Notifications:

Date Contacted:

Contact Method:

Cultural Materials Observed?

Yes

No

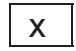

If yes, describe: $\quad$ Artifacts appear to be undisturbed.

Cultural Materials Collected? Yes $\square$ No $x$

If yes, describe: No collection.

General Comments: $\quad$ Road T-16 has been heavily used in the past by ranchers and USGS personnel. From the abundance of weeds growing in the road bed, it appears that T-16 did not see much traffic this year.

Recommendations: None

GPS Coordinates collected?

Yes $\square$ No $x$

If yes, describe (datum, coordinates):

Attach additional documentation, as warranted (photos, profiles, etc.)

Yes

No $x$

If yes, describe: 
Monitor Number:

Monitor Name:

Monitor Date(s):

HKG-09-06

Hollie K. Gilbert and Julie B. Braun

$8 / 26 / 09$

Project:

Routine Monitoring

Site Name/Number:

Kuharski Homestead

Reason for Monitoring:

Assessment of potential impacts due to proximity to public lands.

Findings:

\begin{tabular}{|l|l|}
\hline Type 1 & $\mathrm{x}$ \\
\hline
\end{tabular}

\begin{tabular}{|l|l|}
\hline Type 2 & \\
\hline
\end{tabular}

\begin{tabular}{|l|l|}
\hline Type 3 & \\
\hline
\end{tabular}

Type 4

Impact Agent(s): $\quad$ Recent visitation: Keystone Light can found inside house foundation.

Significance of Impact: $\quad$ Unauthorized visitation.

Did disturbance or impact extend into undisturbed areas?

If yes, describe:

Yes $\square$ No $\quad \mathrm{x}$

Work Halted?

If yes, describe:

Notifications:

Date Contacted:

Contact Method:

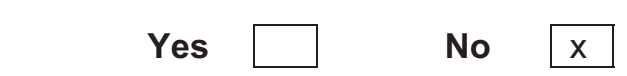

Cultural Materials Observed? Yes $\mathrm{x}$

If yes, describe: Artifacts appear to be undisturbed.

Cultural Materials Collected? Yes $\square$ No $\mathrm{x}$

If yes, describe: No collection.

General Comments: The beer can was removed for disposal.

Rodent burrowing at the blacksmith forge has ceased; no further impacts noted.

Recommendations: Due to the close proximity of this site to the INL boundary and its isolation, annual monitoring visits are recommended.

GPS Coordinates collected?

Yes $\square$ No $x$

If yes, describe (datum, coordinates):

Attach additional documentation, as warranted (photos, profiles, etc.) $\quad$ Yes $\square$ No $\quad x$ If yes, describe: 
Idaho National Laboratory Cultural Resource Management Office

Field Monitoring Form

Monitor Number:

Monitor Name:

Monitor Date(s):

HKG-09-07

Hollie K. Gilbert and Julie B. Braun

$8 / 26 / 09$

Project: $\quad$ Routine Monitoring

Site Name/Number: $\quad$ Richard's Homestead

Reason for Monitoring: Assessment of potential impacts due to proximity to public lands.

\begin{tabular}{l|l|l|l|l|} 
Findings: & Type 1 & $\mathrm{x}$
\end{tabular}$\quad$\begin{tabular}{|l|l|}
\hline Type 2 & Type 3 \\
\hline
\end{tabular}

Impact Agent(s): $\quad$ No impacts noted.

Significance of Impact:

Did disturbance or impact extend into undisturbed areas?

If yes, describe:

Yes $\square$ No $\mathrm{x}$

Work Halted?

If yes, describe:

Notifications: N/A

Date Contacted:

Contact Method: $\quad$ E-mail $\quad \square$ Phone $\square$ Official correspondence, CCN\#:

$\begin{array}{llll}\text { Cultural Materials Observed? } & \text { Yes } \mathrm{X} & \\ \end{array}$

If yes, describe: Artifacts appear to be undisturbed.

Cultural Materials Collected? Yes $\square$ No $\mathrm{x}$

If yes, describe: No collection.

General Comments:

Recommendations: Due to the close proximity of this site to the INL boundary and its isolation, annual monitoring visits are recommended.

GPS Coordinates collected?

Yes $\square$ No $x$

If yes, describe (datum, coordinates):

Attach additional documentation, as warranted (photos, profiles, etc.) Yes $\square$ No $\quad x$ If yes, describe: 
Monitor Number:

Monitor Name:

BRP-09-19

Monitor Date(s):

B. R. Pace, H. K. Gilbert

December 3, 2008

Project:

Site Name/Number:

$\mathrm{N} / \mathrm{A}$

Reason for Monitoring: Routine surveillance

Findings:

\begin{tabular}{|l|l|}
\hline Type 1 & $x$ \\
\hline
\end{tabular}

Type 2

Type 3

Type 4

Impact Agent(s): $\quad$ Off-road vehicle use

Significance of Impact: Not significant. Truck was driven in single line pass along western end of site. Width of track suggests a Humvee.

Did disturbance or impact extend into undisturbed areas?

Yes $\square$ No $\mathrm{x}$

If yes, describe: Vehicles passed through the western end of this site when fences were placed around the archaeological materials in the mid 1980s.

Work Halted?

If yes, describe: N/A

Notifications: $\quad$ None required under Type 1 finding. Follow-up with Ecological Sampling personnel

identified probable cause of tracks and assurance that it will not happen again.

Date Contacted: December 4, 2008

Contact Method:| E-mail $\quad L$ Phone $\quad x \quad$ Official correspondence, CCN\#:

Cultural Materials Observed? Yes $x$ No

If yes, describe: Rock foundation, domestic trash, hand dug (?) ditch

Cultural Materials Collected? Yes $\square$ No $\mathrm{x}$

If yes, describe: No collection.

General Comments: Single pass with large truck did not create any lasting impacts.

Recommendations: Continue periodic monitoring.

GPS Coordinates collected?

Yes $\square$ No $\mathrm{x}$

If yes, describe (datum, coordinates):

Attach additional documentation, as warranted (photos, profiles, etc.) $\quad$ Yes $\square$ No $\quad x$ If yes, describe: 
Monitor Number:

Monitor Name:

Monitor Date(s):

HKG-09-08

Hollie K. Gilbert and Julie B. Braun

$8 / 26 / 09$

Project:

Routine Monitoring

Site Name/Number:

Birch Creek Stage Station

Reason for Monitoring: Assessment of potential impacts due to proximity to public lands and grazing

Findings:

\begin{tabular}{|l|l|}
\hline Type 1 & $\mathrm{x}$ \\
\hline
\end{tabular}

\begin{tabular}{|l|l|}
\hline Type 2 & \\
\hline
\end{tabular}

\begin{tabular}{|l|l|}
\hline Type 3 & \\
\hline
\end{tabular}

Type 4

Impact Agent(s): $\quad$ Tire marks were noted in corral/barn area.

Significance of Impact: $\quad$ Possible unauthorized visitation.

Did disturbance or impact extend into undisturbed areas?

If yes, describe:

Yes $\square$ No $\mathrm{x}$

Work Halted?

If yes, describe:

Notifications:

Date Contacted:

Contact Method:

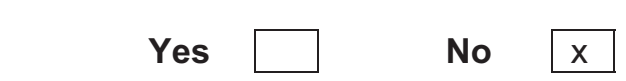

Cultural Materials Observed? Yes $\mathrm{x}$

If yes, describe: $\quad$ Artifacts appear to be undisturbed.

Cultural Materials Collected? Yes $\square$ No $\mathrm{x}$

If yes, describe: No collection.

General Comments: Tire tracks were followed out to a road leading back to the highway.

It does not appear that this location was used by sheepherders this year.

Recommendations: $\quad$ Due to the close proximity of this site to the INL boundary, potential grazing impacts, and its isolation, annual monitoring visits are recommended.

GPS Coordinates collected?

Yes $\square$ No $x$

If yes, describe (datum, coordinates):

Attach additional documentation, as warranted (photos, profiles, etc.) $\quad$ Yes $\square$ No $\quad x$ If yes, describe: 
Monitor Number:

Monitor Name:

Monitor Date(s):

HKG-09-10

Hollie K. Gilbert and Julie Braun

$7 / 14 / 09$

Project:

Routine Monitoring

Site Name/Number:

Powell Stage Station

Reason for Monitoring:

Assessment of site due to high visitation and various project activities in adjacent area.

\begin{tabular}{l|l|l|l|l|}
\hline Findings: & Type 1 & $\mathrm{x}$
\end{tabular}$\quad$\begin{tabular}{|l|l|}
\hline Type 2 & Type 3 \\
\hline
\end{tabular}

Impact Agent(s): $\quad$ Rodent burrowing in southwest corner of rock foundation.

Extensive rodent burrowing in northeast bridge abutments.

Significance of Impact: This disturbance could impact basalt wall stability and cause bridge abutments to slump downhill.

Did disturbance or impact extend into undisturbed areas?

Yes $\mathrm{x}$ No

If yes, describe:

Work Halted? Yes $\square$ No $\mathrm{x}$

If yes, describe:

Notifications: N/A

Date Contacted:

Contact Method:

| E-mail $\bigsqcup$ Phone $\bigsqcup$ Official correspondence, CCN\#:

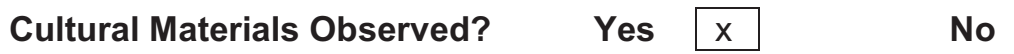

If yes, describe: Glass and metal was noted in disturbed/excavated soils in and around foundation.

Cultural Materials Collected? Yes $\square$ No $\mathrm{x}$

If yes, describe: No collection.

General Comments: If rodent activity increases, we may need to contact Stoller for recommendations on how to discourage rodents from using this site.

Recommendations: None

GPS Coordinates collected?

If yes, describe (datum, coordinates):

Yes $\square$ No $\mathrm{x}$

Attach additional documentation, as warranted (photos, profiles, etc.) $\quad$ Yes $\square$ No $\quad x$ If yes, describe: 
Monitor Number: BRP-09-18

Monitor Name: $\quad$ H. K. Gilbert, B. R. Pace, J. B. Braun

Monitor Date(s): $\quad$ November 20, 2008

Project: $\quad$ BEA-09-11: Geophysical Investigations at the Powell Stage Station

Site Name/Number: $\quad$ 10-BT-2194 (Powell Stage Station)

Reason for Monitoring: Assessment of potential impacts of geophysical surveys including crosscountry use of a 6-wheeler and equipment cart.

Findings:

\begin{tabular}{|l|l|}
\hline Type 1 & $\mathrm{x}$ \\
\hline
\end{tabular}

Type 2

Type 3

Type 4

Impact Agent(s): $\quad$ 6-Wheeler and equipment cart driving transects at $\sim 2$-meter intervals offroad

Significance of Impact: Not significant. Vehicle and cart leave shallow tracks through soft surface soils but do not impact harder gravel deposits. Impacts to ground surfaces appear to be minimal, not much greater than intensive pedestrian activity.

Did disturbance or impact extend into undisturbed areas?

Yes $x$

No

If yes, describe: Surveys are being conducted in areas that have not been recently disturbed.

\begin{tabular}{lll|l} 
Work Halted? & Yes \\
No & $\mathrm{x}$ \\
\hline
\end{tabular}

If yes, describe:

Notifications: None required under Type 1 finding.

Date Contacted:

Contact Method: $\mid$ E-mail $\quad \square$ Phone $\bigsqcup$ Official correspondence, CCN\#:

$\begin{array}{llll}\text { Cultural Materials Observed? } & \text { Yes } & \mathrm{x} & \end{array}$

If yes, describe: ATV passed through the historic archaeological materials at the Powell Stage station with no appreciable negative impacts.

Cultural Materials Collected?

Yes $\square$ No $x$

If yes, describe: No collection.

General Comments: 6-wheeler and cart leave faint tracks through soft soils and no indications of passage over gravel surfaces. No artifacts were displaced or broken. Impacts are comparable to intensive foot traffic. Geophysical data collected from these locations may be useful in archaeological research applications

Recommendations: $\quad$ Continue archaeological surveys ahead of all 6-wheeler use in off-road settings, facilitate avoidance as necessary, and monitor identified resources for impacts.

GPS Coordinates collected?

Yes $\square$ No $x$

If yes, describe (datum, coordinates):

Attach additional documentation, as warranted (photos, profiles, etc.) Yes No $x$ If yes, describe: 
A: Historic Trails 
Idaho National Laboratory Cultural Resource Management Office Field Monitoring Form

Monitor Number: $\quad$ HKG-09-11

Monitor Name: $\quad$ Hollie K. Gilbert and Julie Braun

Monitor Date(s): $\quad 5 / 19 / 09$

Project: $\quad$ Routine Monitoring

Site Name/Number: $\quad$ Goodale's Cutoff/T-1

Reason for Monitoring: On-going monitoring

Findings:

\begin{tabular}{|l|l|}
\hline Type 1 & $\mathrm{x}$ \\
\hline
\end{tabular}

\begin{tabular}{|l|l|}
\hline Type 2 & \\
\hline
\end{tabular}

\begin{tabular}{|l|l|}
\hline Type 3 & \\
\hline
\end{tabular}

Impact Agent(s): $\quad$ None noted, road appears to be lightly used.

Significance of Impact:

Did disturbance or impact extend into undisturbed areas?

If yes, describe:

Work Halted?

If yes, describe:

Notifications: N/A

Date Contacted:

Contact Method:

| E-mail $\square$ Phone $\square$ Official correspondence, CCN\#:

$\begin{array}{llll}\text { Cultural Materials Observed? } & \text { Yes } \square \text { No } & x\end{array}$

If yes, describe:

\begin{tabular}{llll} 
Cultural Materials Collected? Nes & No & $x$ \\
\hline
\end{tabular}

If yes, describe: No collection.

General Comments: Road does not appear to be as heavily traveled as it was last year.

Recommendations: $\quad$ Due to the historic significance of this road, it should be monitored on an annual basis.

GPS Coordinates collected?

Yes $\square$ No $x$

If yes, describe (datum, coordinates):

Attach additional documentation, as warranted (photos, profiles, etc.) $\quad$ Yes $\square$ No \begin{tabular}{ll|l|}
\hline \\
\end{tabular} If yes, describe: 
Monitor Number:

Monitor Name:

Monitor Date(s):

HKG-09-12

Hollie K. Gilbert and Julie B. Braun

$8 / 7 / 09$

Project:

Routine Monitoring

Site Name/Number: $\quad$ Road/trail T-16

Reason for Monitoring: $\quad$ Assessment of potential impacts of ongoing use of road T-16.

\begin{tabular}{l|l|l|l|l|}
\hline Findings: & Type 1 & $\mathrm{x}$ & Type 2 & Type 3 \\
\hline
\end{tabular}

Impact Agent(s): $\quad$ No new impacts noted.

Significance of Impact:

Did disturbance or impact extend into undisturbed areas?

If yes, describe:

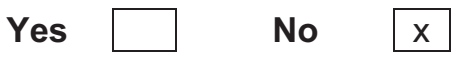

Work Halted?

If yes, describe:

Notifications:

Date Contacted:

Contact Method:

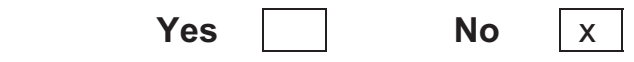

Cultural Materials Observed?

If yes, describe:

$\mathrm{N} / \mathrm{A}$

Cultural Materials Collected? Yes $\square$ No $\mathrm{x}$

If yes, describe: No collection.

General Comments: Road T-16 has been heavily used in the past by ranchers and USGS personnel. From the abundance of weeds growing in the road bed, it appears that T-16 did not see much traffic this year. Gravel added to road bed from "dump and run" activity (adding gravel to muddy areas) has taken away a certain historical element of this road.

Recommendations: None

GPS Coordinates collected?

If yes, describe (datum, coordinates):

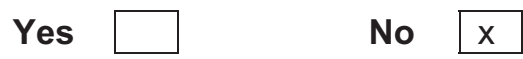

Attach additional documentation, as warranted (photos, profiles, etc.)

Yes

No $x$ If yes, describe: 
A: Nuclear Resources 
Monitor Number:

Monitor Name:

JBB-10-01

Monitor Date(s):

J. B. Braun

6/16/09, 9/22/09

Project:

Not Applicable

Site Name/Number:

Experimental Breeder Reactor I

Reason for Monitoring: Routine monitoring

Findings:

\begin{tabular}{|l|l|}
\hline Type 1 & $\mathrm{x}$ \\
\hline
\end{tabular}

\begin{tabular}{|l|l|}
\hline Type 2 & \\
\hline
\end{tabular}

\begin{tabular}{|l|l|}
\hline Type 3 & \\
\hline
\end{tabular}

Type 4

Impact Agent(s): $\quad$ No new impacts observed in June or September. However, there is still not an adequate water drainage system in place for the reactor building.

Significance of Impact: Failure to provide adequate water drainage away EBR I may create water leakage, effluecence, and eventual erosion of bricks and mortar which will result in an adverse impact. This issue has previously been reported to DOE-ID and BEA.

Did disturbance or impact extend into undisturbed areas? If yes, describe:

Work Halted?

If yes, describe:

Yes $\square$ No $\mathrm{x}$

Notifications:

Date Contacted:

Contact Method: | E-mail Phone Official correspondence, CCN\#:

Cultural Materials Observed? Yes $\mathrm{x}$

No

If yes, describe: $\quad$ EBR I is listed on the National Register of Historic Places as a National Historic Landmark, one of only three such buildings in the state of Idaho.

Cultural Materials Collected? Yes $\square$ No $\mathrm{x}$

If yes, describe: No collection.

General Comments: A "Save America's Treasure" grant was obtained in 2002 and the funding used to repoint/replace damaged brick and mortar on the reactor building. It was recommended at that time and each year since then that an adequate water drainage system was needed to protect against similar damage in the future.

Recommendations: Install an adequate water drainage system.

GPS Coordinates collected? If yes, describe (datum, coordinates):

Yes $\square$ No $\mathrm{X}$

Attach additional documentation, as warranted (photos, profiles, etc.) $\quad$ Yes $\quad X \quad$ No $\square$ If yes, describe: Photos on file. 
Monitor Number:

Monitor Name:

JBB-10-02

Monitor Date(s):

J. B. Braun

6/16/09, 9/22/09

Project:

Not Applicable

Site Name/Number:

Heat Transfer Reactor Experiment Engines and Locomotive

Reason for Monitoring: Routine monitoring

Findings:

\begin{tabular}{|l|l|}
\hline Type 1 & $\mathrm{x}$ \\
\hline
\end{tabular}

\begin{tabular}{|l|l|}
\hline Type 2 & \\
\hline
\end{tabular}

\begin{tabular}{|l|l|}
\hline Type 3 & \\
\hline
\end{tabular}

Type 4

Impact Agent(s): $\quad$ No new impacts observed in June or September. However, exposure to and. weather (i.e., sun, rain, snow, freezing, thawing) and nesting birds have continued to impact the Heat Transfer Reactor Experiment (HTRE) engines locomotive

Significance of Impact: $\quad$ Continued exposure of the HTREs and locomotive to the elements will result in continued deterioration and may also eventually result in an adverse impact. These issues have previously been reported to DOE-ID and BEA.

Did disturbance or impact extend into undisturbed areas?

Yes

No

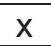
If yes, describe:

Work Halted? If yes, describe:

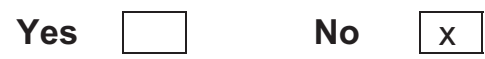

Notifications:

Date Contacted:

Contact Method: | E-mail Phone Official correspondence, CCN\#:

Cultural Materials Observed? Yes $x$ No

If yes, describe: The Heat Transfer Reactor Experiment engines and associated locomotive are eligible for listing on the National Register of Historic Places.

Cultural Materials Collected? Yes $\square$ No $\mathrm{x}$ If yes, describe: No collection.

General Comments: A nomination package for the HTREs was prepared and submitted to DOE-ID in FY 2006. It has not been transmitted to the Keeper of the National Register. A decision regarding how to protect/preserve the HTREs and locomotive must be reached before further deterioration can occur.

Recommendations: $\quad$ Expand nomination to include the locomotive. Research how to preserve/ protect HTREs and locomotive given funding limitations.

GPS Coordinates collected?

Yes

No

If yes, describe (datum, coordinates):

Attach additional documentation, as warranted (photos, profiles, etc.)

Yes

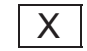

No

If yes, describe: Photos on file. 


\section{A: Projects}


Monitor Number: $\quad$ BRP-09-15

Monitor Name:

B. R. Pace, H. K. Gilbert

Monitor Date(s): $\quad$ October 13, 2008 and March 16, 2009

Project:

Site Name/Number:

National Security Test Range T-25 Access Road

10-JF-85, 10-JF-84, 10-JF-83, 10-JF-80, 10-JF-78, 10-JF-77, 10-BM-123, and BEA-06-20-07

Reason for Monitoring: Revisits to previously recorded sites in the area of potential effect for road improvements along the T-25 power line road leading to the National Security

Test Range

Findings:

\begin{tabular}{|l|l|}
\hline Type 1 & $\mathrm{x}$ \\
\hline
\end{tabular}

Type 2

Type 3

Type 4

Impact Agent(s): $\quad$ Power pole inspection, maintenance, and repair have caused ground disturbance around power poles and under the lines. Road construction has heavily impacted a linear path through the site area and ongoing maintenance (grading, graveling, snow removal, vehicle turnarounds) continues to cause impacts. Road is heavily used now and can support speeds in excess of 30 mph.

Significance of Impact: Past impacts during power line and road maintenance have caused significant impacts to portions of the sites. Undisturbed deposits still remain in surrounding areas and care is being taken to preserve these materials.

Did disturbance or impact extend into undisturbed areas?

Yes $\mathrm{x}$ No

If yes, describe: New turnarounds were observed and sandy soils from undisturbed areas adjacent to the road are piled up with gravel in the road side ricks.

$\begin{array}{llll}\text { Work Halted? } & \text { Yes } \\ \text { No } & \mathrm{x}\end{array}$

If yes, describe: N/A

Notifications: $\quad$ Consultation continues with project management to halt impacts and prevent escalation to Type II situation.

Date Contacted: March and July 2009

Contact Method: $\mid$\begin{tabular}{l|l|l|l|l}
\hline E-mail & $x$ & Phone & & Official correspondence, CCN\#:
\end{tabular}

Cultural Materials Observed? Yes $\mathrm{x}$ No $\square$

If yes, describe: Lithic flakes observed in all areas. No new artifacts observed.
Cultural Materials Collected?
Yes
No $x$

If yes, describe: No collection.

General Comments: Pin flags are placed along sensitive stretches of the road to prevent additional grading. However, continued maintenance and heavy use of the road does appear to be creating a wider corridor of disturbance.

Recommendations: Test excavations should be conducted along the edges of the road in all site areas to determine if sensitive artifacts are present. Until this evaluation is complete, road work should be restricted in the sensitive areas.

GPS Coordinates collected?

Yes

No $x$

If yes, describe (datum, coordinates):

Attach additional documentation, as warranted (photos, profiles, etc.)

Yes

No $x$ If yes, describe: 
Monitor Number: BRP-09-16

Monitor Name: $\quad$ B. R. Pace

Monitor Date(s): $\quad$ October 27, 2008

Project: National Security Test Range T-25 Access Road

Site Name/Number: $\quad$ 10-BM-124

Reason for Monitoring: Soil disturbance needed within 50 meters of archaeological site boundary. Heavy equipment operations monitored in case artifacts were unexpectedly encountered.

Findings:

\begin{tabular}{|l|l|}
\hline Type 1 & $x$ \\
\hline
\end{tabular}

Type 2

Type 3

Type 4

Impact Agent(s): $\quad$ Heavy equipment recontouring soil in low area where water accumulates.

Significance of Impact: Not significant. No artifacts observed in disturbed soil.

Did disturbance or impact extend into undisturbed areas?

Yes

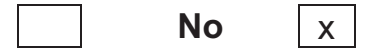

If yes, describe:

Work Halted?

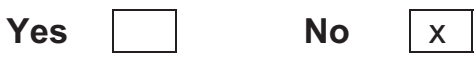

If yes, describe: N/A

Notifications: None required. No impacts to cultural materials

Date Contacted:

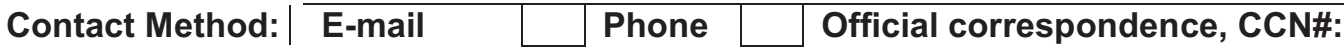

Cultural Materials Observed? Yes $\square$ No $\quad x$

If yes, describe:

Cultural Materials Collected? Yes $\square$ No $\mathrm{x}$

If yes, describe:

General Comments: No artifacts observed. Site boundary does not appear to extend to area adjacent to T-25.

Recommendations: No further work required.

GPS Coordinates collected?

If yes, describe (datum, coordinates):

Yes $\square$ No $x$

Attach additional documentation, as warranted (photos, profiles, etc.) $\quad$ Yes $\square$ No $\quad x$ If yes, describe: 
Monitor Number: $\quad$ BRP-09-17

Monitor Name: $\quad$ B. R. Pace

Monitor Date(s): $\quad$ November 10, 2008

Project: $\quad$ National Security Test Range Safety Fan

Site Name/Number: N/A

Reason for Monitoring: Routine surveillance to evaluate project compliance with recommendations to protect cultural resources

Findings:

\begin{tabular}{|l|l|}
\hline Type 1 & $\mathrm{x}$ \\
\hline
\end{tabular}

Type 2

Type 3

Type 4

Impact Agent(s): $\quad$ Off-road vehicle use

Significance of Impact: Not significant. Truck was driven in single line pass around the perimeter of the safety fan along a path marked to avoid passage through sensitive archaeological resources.

Did disturbance or impact extend into undisturbed areas?

If yes, describe: The safety fan passes through areas that have not been disturbed.

$\begin{array}{llll}\text { Work Halted? } & \text { Yes } \\ \end{array}$

If yes, describe: N/A

Notifications: $\quad$ None required under Type 1 finding.

Date Contacted:

Contact Method: $\mid$ E-mail $\quad L \quad$ Phone $\quad x \quad$ Official correspondence, CCN\#:

Cultural Materials Observed? Yes $\square$ No $\mathrm{X}$

If yes, describe:

Cultural Materials Collected? Yes $\square$ No $\mathrm{x}$

If yes, describe:

General Comments: Single pass with truck during sign installation did not create any lasting impacts. In most places there is no evidence of its passage.

Recommendations: Walking this perimeter with project personnel along to do light maintenance on signs is a great way to prevent impacts to the cultural resources known to exist in the area because it eliminates the need to use vehicles or ATV's. Work with project personnel to secure support for this effort again next year.

GPS Coordinates collected?

Yes No $\quad \mathrm{x}$

If yes, describe (datum, coordinates):

Attach additional documentation, as warranted (photos, profiles, etc.)

Yes

No $x$ If yes, describe: 
Monitor Number: $\quad$ BRP-09-20

Monitor Name: $\quad$ B. R. Pace, J. B. Braun in 2008 and multiple representatives from DOE-ID and Caroline Smith from the Shoshone-Bannock Tribes in 2009

Monitor Date(s): $\quad$ October 22, 2008 and August 12, 2009

Project: $\quad$ Big Lost River Trenches

Site Name/Number: $\quad$ 10-BT-2189 at BLR-8 Trenches, 10-BT-2192, 10-BT-2193, and 10-BT-2194

(Powell Stage Station) at Saddle Trenches

Reason for Monitoring: Routine surveillance of archaeological sites impacted by the Big Lost River Trenches project, including DOE-ID and tribal participants in 2009.

Findings:

\begin{tabular}{|l|l|}
\hline Type 1 & $x$ \\
\hline
\end{tabular}

Type 2

Type 3

Type 4

Impact Agent(s): $\quad$ Heavy equipment originally. Revegetated areas are attractive to local herds of antelope and deer. Grazing by these native ungulates has increased and so have the associated impacts (trampling, bedding areas, paths, etc.)

Significance of Impact: None of the impacts from native ungulates are significant.

Did disturbance or impact extend into undisturbed areas? $\quad$ Yes $\square$ No $\quad x$ If yes, describe: Backfilling and revegetation were carefully designed to prevent disturbance outside original area of potential effect for trenches. Grazing, trampling, and wind erosion are widespread in and around the old trenches.

Work Halted? Yes No $\mathrm{x}$

If yes, describe: N/A

Notifications: $\quad$ None required under Type 1 Finding.

Date Contacted: N/A Contact Method: $\mid$ E-mail $\downarrow$ Phone $\square$ Official correspondence, CCN\#:

Cultural Materials Observed? Yes $\mathrm{x}$ No

If yes, describe: Trenches were originally placed inside the boundaries of prehistoric archaeological sites and the Powell Stage Station. A wide range of artifacts occur throughout the trenching areas (BLR-8 and Saddle) and were observed during trenching, backfilling, and revegetation operations in both disturbed and undisturbed contexts. New surface finds are common, particularly at 10-BT-2189 in the BLR-8 trenching location where wind erosion alternately exposes and covers artifacts resting in blowout areas and along the edges of the old trench locations.

\begin{tabular}{llll} 
Cultural Materials Collected? & Yes \\
& No & $x$ \\
\hline
\end{tabular} If yes, describe: No collection.

General Comments: Grazing impacts have been observed at the trenches since they were backfilled in Fall, 2007. No other impacts are apparent and plant re-growth is slow but acceptable. Native species are becoming dominant and weeds are minimal.

Recommendations: Continue yearly monitoring.

GPS Coordinates collected?

Yes

No $x$

If yes, describe (datum, coordinates):

Attach additional documentation, as warranted (photos, profiles, etc.)

Yes

No $x$ If yes, describe: 
Monitor Number: $\quad$ BRP-09-25

Monitor Name: $\quad$ B. R. Pace, Caroline Smith

Monitor Date(s): $8 / 19 / 09$

Project: $\quad$ BEA-09-05: Ordnance Surveys--Railcar Area

Site Name/Number: $\quad$ 10-BT-2050, 10-BT-2051, 10-BT-2052, 10-BT-2053

Reason for Monitoring: Assessment of potential impacts of ongoing ordnance surveys and cleanup, including cross-country geophysical surveys with ATV and cart.

Findings:

\begin{tabular}{|l|l|}
\hline Type 1 & $\mathrm{x}$ \\
\hline
\end{tabular}

\begin{tabular}{|l|l|}
\hline Type 2 & \\
\hline
\end{tabular}

Type 3

Type 4

Impact Agent(s):

6-Wheeler and equipment cart driving transects at $\sim 2$-meter intervals offroad

Significance of Impact: Vehicle and cart leave shallow tracks through soft surface soils but do not impact harder gravel deposits. Impacts to ground surfaces appear to be minimal, not much greater than intensive pedestrian activity.

Did disturbance or impact extend into undisturbed areas?

Yes $x$

No

If yes, describe: Surveys are being conducted in areas that have not been disturbed since ordnance testing in the 1940s

Work Halted?

If yes, describe:

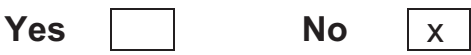

Notifications: $\quad$ None required under Type 1 finding.

Date Contacted:

Contact Method:| E-mail $\quad \square$ Phone $\square$ Official correspondence, CCN\#:

Cultural Materials Observed? Yes $\mathrm{x}$ No $\square$

If yes, describe: ATV passed through the boundaries of three known archaeological sites (10-BT-2050, 10-BT-2051, 10-BT-2052) with assemblages dominated by lithic debris with no appreciable negative impacts.

Cultural Materials Collected?

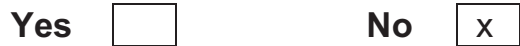

If yes, describe: No collection.

General Comments: 6-wheeler and cart leave faint tracks through soft soils and no indications of passage over gravel surfaces. No artifacts were displaced or broken. Impacts are comparable to intensive foot traffic. Geophysical data collected from these locations may be useful in archaeological research applications

Recommendations: Continue archaeological surveys ahead of all 6-wheeler use in off-road settings, facilitate avoidance as necessary, and monitor identified resources for impacts. Complete intensive archaeological investigations possibly including test excavations in advance of additional cleanup or remediation resulting from the geophysical surveys. Directly monitor any proposed removal of ordnance or debris from inside the boundaries of known cultural resources.

GPS Coordinates collected?

Yes

No $x$

If yes, describe (datum, coordinates):

Attach additional documentation, as warranted (photos, profiles, etc.)

Yes

No $x$ If yes, describe: 
Monitor Number:

Monitor Name:

BRP-09-26

Monitor Date(s):

B. R. Pace, Caroline Smith

8/19/09, 9/25/09

Project:

BEA-09-15: Explosive Magazine Facility

Site Name/Number: BEA-08-03-22

Reason for Monitoring: Tour of proposed project area near archaeological site and confirmation of avoidance during project implementation.

\begin{tabular}{|l|l|l|l|l|}
\hline Findings: & Type 1 & $\mathrm{x}$ & Type 2 & Type 3 \\
\hline
\end{tabular}

Impact Agent(s): $\quad$ No impacts have occurred.

Significance of Impact: N/A

Did disturbance or impact extend into undisturbed areas?

If yes, describe:

Work Halted? Yes $\square$ No $\mathrm{x}$

If yes, describe:

Notifications: N/A

Date Contacted:

Contact Method: | E-mail

Phone $\square$ Official correspondence, CCN\#:

Cultural Materials Observed? Yes $\mathrm{x}$ No

If yes, describe: Isolated flakes of obsidian are eroding from a sand dune to the west of the project area have not been impacted by project activities. Test excavation confirmed no sensitive materials are present in the area proposed for road improvement.

Cultural Materials Collected?

Yes $\square$ No $x$

If yes, describe: No collection.

General Comments: Visit confirmed that all surface artifacts are located to the west of proposed project work along the existing access road. Shovel test excavations in sandy soils within and adjacent to the road confirmed that subsurface cultural materials do not extend into the area of project ground disturbance. Second visit confirmed project avoidance of sensitive area.

Recommendations: No further work recommended.

GPS Coordinates collected? Yes $\square$ No $x$

If yes, describe (datum, coordinates):

Attach additional documentation, as warranted (photos, profiles, etc.) Yes No $x$ If yes, describe: 
Idaho National Laboratory Cultural Resource Management Office Field Monitoring Form

Monitor Number: HKG-09-09

Monitor Name: $\quad$ H. K. Gilbert, B. R. Pace, Caroline Smith

Monitor Date(s): $\quad 3 / 16 / 09,5 / 1 / 09,5 / 15 / 09,5 / 25 / 09,7 / 14 / 09,7 / 22 / 09,8 / 19 / 09,8 / 26 / 09,9 / 23 / 09$

Project:

Site Name/Number:

Power Burst Facility/Critical Infrastructure Test Range Complex

Reason for Monitoring: 10-BT-1991, 10-BT-2046

Routine monitoring of ground disturbing activities within the PBF/CITRC area particularly in the vicinity of PER-632 and the Waste Experimental Reduction Facility (WERF) where human remains have been discovered in secondary and original contexts and as required by LWP-8000 and MCP-3480.

Findings: $\quad$\begin{tabular}{|l|l|l|l|}
\hline Type 1 & $\mathrm{x}$ & Type 2 & Type 3 \\
\hline
\end{tabular}

Impact Agent(s): $\quad$ No new impacts observed.

Significance of Impact: $\mathrm{N} / \mathrm{A}$

Did disturbance or impact extend into undisturbed areas?

If yes, describe:

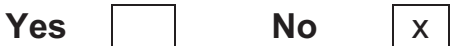

Work Halted?

If yes, describe:

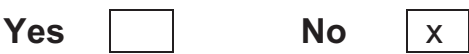

Notifications: N/A

Date Contacted:

Contact Method:| E-mail $\quad$ Phone $\quad$ Official correspondence, CCN\#:

Cultural Materials Observed? Yes $\mathrm{x}$ No

If yes, describe: Isolated flakes of obsidian are eroding from a sand dune to the west of the project area have not been impacted by project activities. Test excavation confirmed no sensitive materials are present in the area proposed for road improvement.

Cultural Materials Collected? Yes $\square$ No $\mathrm{x}$

If yes, describe: No collection.

General Comments: No artifacts or human remains observed in project excavations (training exercises, power line testing, cell tower installation, electrical trenching, DD\&D)

Recommendations: Continue routine monitoring of excavation projects in this sensitive area per the requirements of LWP-8000, MCP-3480, and the wishes of the ShoshoneBannock Tribes. Provide sensitivity training for workers.

GPS Coordinates collected?

Yes No $\quad x$

If yes, describe (datum, coordinates):

Attach additional documentation, as warranted (photos, profiles, etc.)

Yes

No $\mathrm{x}$ If yes, describe: 